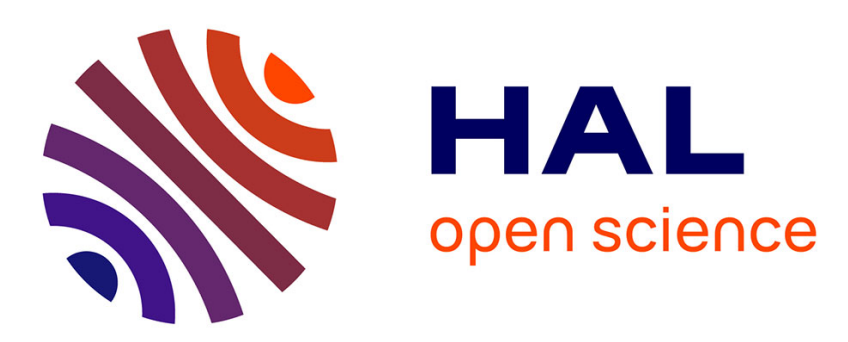

\title{
Recovery of Metal Oxide Nanomaterials from Electronic Waste Materials
}

Heba H El-Maghrabi, Amr A Nada, Fathi S Soliman, Patrice Raynaud, Yasser M Moustafa, Gomaa a M Ali, Maged F Bekheet

\section{- To cite this version:}

Heba H El-Maghrabi, Amr A Nada, Fathi S Soliman, Patrice Raynaud, Yasser M Moustafa, et al.. Recovery of Metal Oxide Nanomaterials from Electronic Waste Materials. Waste Recycling Technologies for Nanomaterials Manufacturing, pp.203-227, In press, 10.1007/978-3-030-68031-2_8 . hal03272410

\section{HAL Id: hal-03272410 https://hal.science/hal-03272410}

Submitted on 8 Nov 2021

HAL is a multi-disciplinary open access archive for the deposit and dissemination of scientific research documents, whether they are published or not. The documents may come from teaching and research institutions in France or abroad, or from public or private research centers.
L'archive ouverte pluridisciplinaire HAL, est destinée au dépôt et à la diffusion de documents scientifiques de niveau recherche, publiés ou non, émanant des établissements d'enseignement et de recherche français ou étrangers, des laboratoires publics ou privés. 


\title{
Recovery of metal oxide nanomaterials from electronic waste materials
}

\author{
Heba H. El-Maghrabi 1,*, Amr A. Nada 2,3,", Fathi S. Soliman ${ }^{1}$, Patrice Raynaud ${ }^{3}$, Yasser

\section{Moustafa ${ }^{2}$, Gomaa A.M. Ali ${ }^{4,5}$, Maged F. Bekheet ${ }^{6}$}

${ }^{1}$ Department of Refining, Egyptian Petroleum Research Institute, Cairo, Nasr city P.B. 11727, Egypt.

${ }^{2}$ Department of Analysis and Evaluation, Egyptian Petroleum Research Institute, Cairo, Nasr city P.B. 11727, Egypt

${ }^{3}$ Laboratoire Plasma et Conversion de l'Energie (LAPLACE), Université de Toulouse, CNRS, INPT, UPS, Toulouse, 31071, France

${ }^{4}$ Chemistry Department, Faculty of Science, Al-Azhar University, Assiut, 71524, Egypt

${ }^{5}$ Al-Azhar Center of Nanoscience and Applications (ACNA), Al-Azhar University, Assiut 71524, Egypt

6 Fachgebiet Keramische Werkstoffe/Chair of Advanced Ceramic Materials, Institut für Werkstoffwissenschaften und -technologien, Technische Universität Berlin, Hardenbergstraße 40, 10623 Berlin, Germany

*sCorresponding authors: E-mail: chem_amr@yahoo.com, amr.nada@umontpellier.fr (A.A. Nada), and hebachem@yahoo.com (H.H. El-Maghrabi).

\section{Contents}

Abstract....

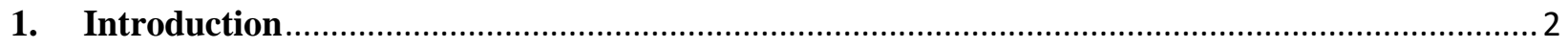

2. Recent categories and strategies of metal oxide recovery .................................................... 7

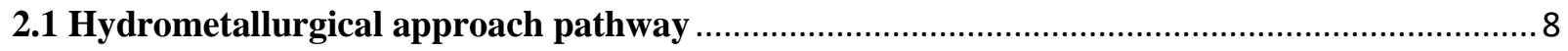

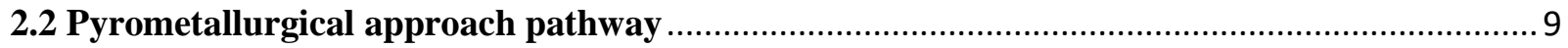

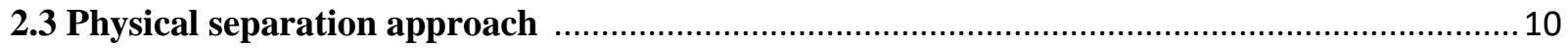




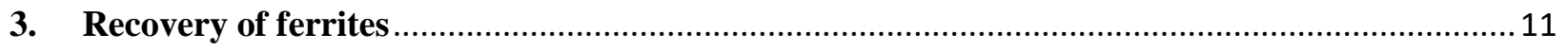

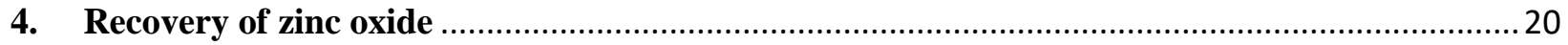

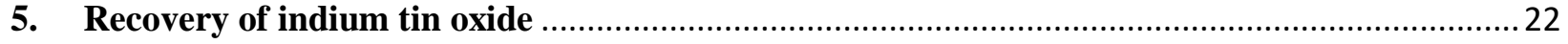

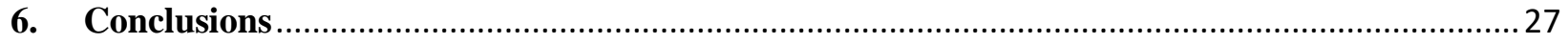

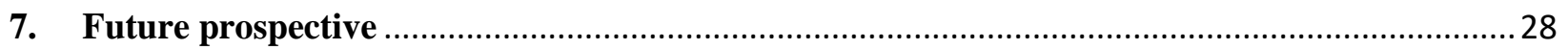

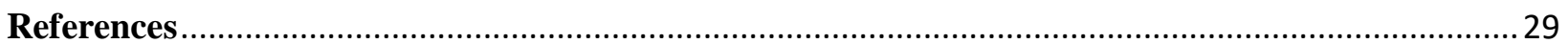

\begin{abstract}
The exploitation of spent battery and electronic waste for the recovery and preparation of metal oxide nanomaterials (MONMs) is vital for technology, economical, sustainable, and environmental research. The recovery of MONMs through recycling waste materials reduces environmental pollutions and saves the primary resources due to industrial consumption. However, the economic benefits of recycling electronic waste for the recovery of these high-value MONMs have still been debated because of the low purity and stability of recovered materials restricting their commercial use. In this chapter, we discuss the motivation and importance of waste recycling for the recovery of nanomaterials, focusing on the possible techniques that can be applied for the efficient synthesis of commercial-grade MONMs (e.g., ferrites, zinc oxides, indium oxides, tin oxides, etc.) with high purity at a minimal cost. Besides, the profit of recovered MONMs in potential applications for wastewater remediation and renewable energy production are addressed.
\end{abstract}

Keywords: Nanomaterials, Metal oxides, Waste recycling, Environmental pollution. Renewable energy.

\title{
1. Introduction
}

Recycling waste materials to recover high-value end-products is probably the most effective environmental preservation [1]. The goals of recycling are to achieve less natural spent 
consumption and reduce the amount of trash, as illustrated in Fig. 1. It is important to recycle waste materials with the lowest possible energy consumption [2]. Thus, the raw materials can be recovered several times through the recycling processes. Recycling is designed to reduce the consumption of energy and save natural resources. Up to date, we are far uptake from a lockedloop material cycle because we are not able to recycle all the waste materials (Fig. 2). A closedloop platform has three fundamentals as following: gathering, processing, and purchase. The gathering is rerouting and collecting spent wastes for recycling and treatment. In the processing, the collected spent wastes are re-manifested for fabricating a new output. Finally, the freshly synthetic output is then sold to a tertiary party before reprocessing and repeat the operation once more. Regarding the entire closing of the spent recycle, the most crucial aspect is to beat several restrictions enjoined in reprocess like output layout, process thermodynamics, recovery methods, social behavior, and economics []ㅡ.

It could be announced that recovery and the up-scale recycling for several spent wastes (e.g., newspapers, glass bottles, cans, polymers, electronics, and batteries) are recently echoed in many countries of all the world [4]. Converting waste into fresh, valuable, and vendible products might be an essential strategy in boosting earnest recovery efforts to prospect desirable economic feedback with polity subsidization [5-10]. Several nanomaterials (metals, metal oxides and hydroxides) such as ferrites, $\mathrm{TiO}_{2}, \mathrm{Ag}, \mathrm{Fe}, \mathrm{Fe}-\mathrm{O}, \mathrm{Au}, \mathrm{ZnO}, \mathrm{SiO}_{2}$ and hydroxyapatite have been recovered from waste materials by different recycling processes [11]. These recovered nanomaterials could be extensively used in many applications, such as in renewable energy solar cells, catalysis, water remediation, and supercapacitors [12]. Many researchers have reported nanomaterials recovery from electronic waste by different recycling processes under available conditions in most research laboratories, as revealed in Table 1. 
The spent batteries are the most predominant waste materials recycled to recover different nanomaterials [13-18]. Nowadays, batteries are widely used as mobile sources of energy for many purposes. Annual battery consumption is estimated at 8,6 , and 1 billion units annually in

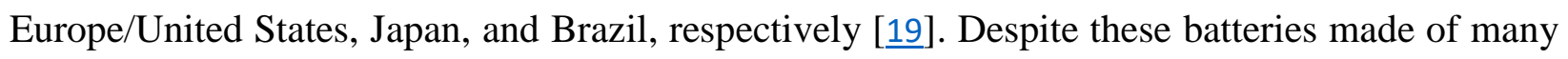
valuable materials that can be recovered, they are usually disposed of as spent waste after their end life. Nevertheless, scientists recently made some attempts to recover these valuables metal and metal oxides from the spent batteries waste, such as wastes of $\mathrm{Zn}-\mathrm{C}$, $\mathrm{Li}-\mathrm{ion}, \mathrm{Ni}-\mathrm{MH}$, and zincmanganese oxide alkaline batteries [요 20-22]. Several nanoparticles (NPs) such as Fe, Co, Mn, Li, $\mathrm{Ag}, \mathrm{Au}, \mathrm{Zn}, \mathrm{Ti}, \mathrm{Pd}, \mathrm{Ni}, \mathrm{Cu}$, and rare earth elements could be recovered from the spent batteries wastes $[\underline{8}, \underline{21}, \underline{23}, \underline{24}]$. Analogous with these, various oxide nanomaterials such as $\mathrm{Co}_{3} \mathrm{O}_{4}, \mathrm{MnO}_{2}$, $\mathrm{ZnO}, \mathrm{ZnMn}_{2} \mathrm{O}_{4}, \mathrm{Ni}-\mathrm{Mn}-\mathrm{Co}-\mathrm{Zn}$ ferrites, and $\mathrm{MnO}_{2} / \mathrm{RGO}$ could also be synthesized from recovered materials from the spent batteries wastes $[\underline{8}, \underline{20}, \underline{21}, \underline{24}, \underline{25}]$.

Dry cell batteries (i.e., alkaline batteries) represent about $89 \%$ of commercially available batteries globally, whereas hundreds of million pieces of dry batteries are manufactured per year $[\underline{26}, \underline{27}]$. Thus, the disposal of the spent dry batteries is a huge issue that can not be neglected $[\underline{20}, \underline{27}, \underline{28}]$. In various countries, gathering ways were established to manage the spent dry batteries wastes. However, a considerable quantity is still left to be castaway along with household spent. Burying, burning, and recycling are the three main administration routes for the spent dry batteries [29]. The highest practical strategies for the finite availability of sites were incineration and recycling. Recycling is also a viable solution for addressing these serious problems associated with spent waste [30-32].

Accordingly, this chapter aims to discuss the most novel and environmentally friendly technologies for recycling various batteries and electronic wastes to recover valuable metals oxide 
nanomaterials such as metal ferrites, zinc oxide, and indium tin oxide. The possible applications of recovered nanomaterials in different fields such as catalysis, water treatment, photocatalyst, electrocatalysis, supercapacitors will also be demonstrated.

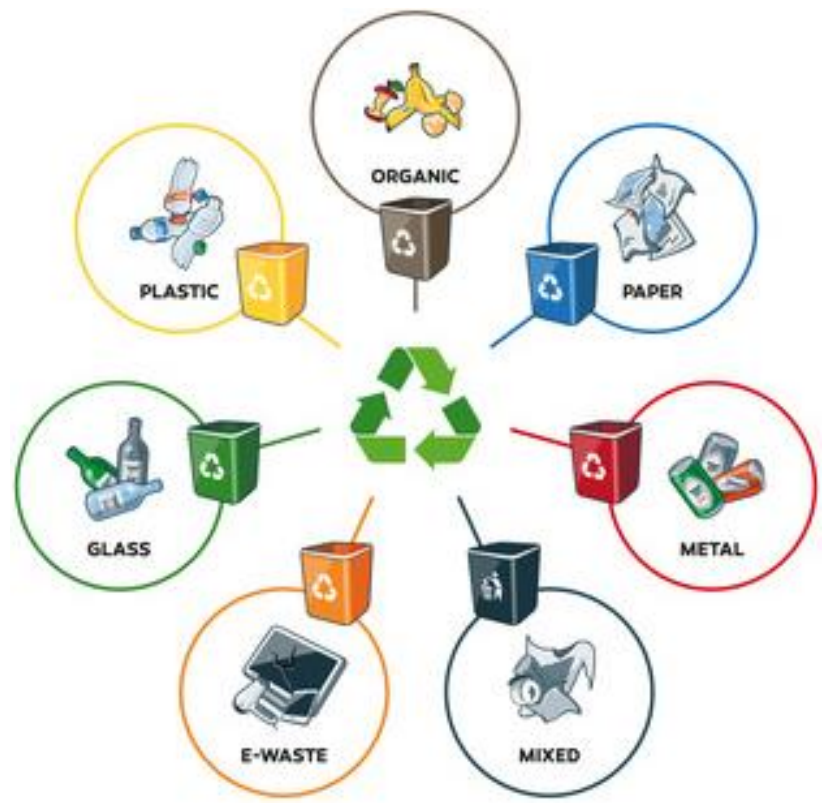

Fig. 1 Recycling and recovery of waste.
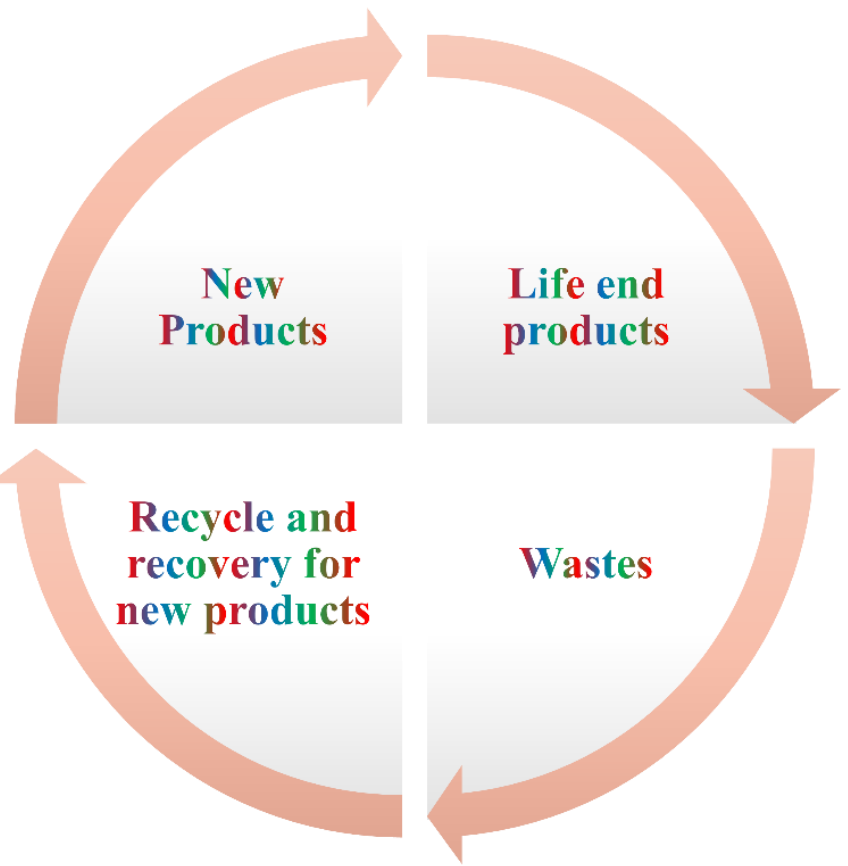
Fig. 2 Closed-loop materials cycle.

Table 1 Nano metal oxides recovered from recyclable waste

\begin{tabular}{|c|c|c|c|c|}
\hline Waste & Oxides & Methods & Recovery (\%) & Ref. \\
\hline $\begin{array}{l}\text { Zn-C, Zn-Mn } \\
\text { batteries }\end{array}$ & $\begin{array}{l}\mathrm{Ni}-\mathrm{Mn}-\mathrm{Zn} / \mathrm{Mn}- \\
\mathrm{Zn} \text { ferrites }\end{array}$ & $\begin{array}{l}\text { Co-precipitation, } \\
\text { Sol-gel, and } \\
\text { leaching }\end{array}$ & $\begin{array}{l}56 \mathrm{Fe} \text { and } 97 \\
\text { of } \mathrm{Mn} \text { and } \mathrm{Zn}\end{array}$ & {$[\underline{13}, \underline{33}, \underline{34}]$} \\
\hline $\mathrm{Li}$ ion batteries & Co Ferrites & $\begin{array}{l}\text { Sol-gel, } \\
\text { coprecipitation, } \\
\text { hydrothermal }\end{array}$ & -- & [35-37] \\
\hline $\begin{array}{l}\mathrm{MnO}_{2-} \mathrm{Zn} \quad \mathrm{dry} \\
\text { batteries }\end{array}$ & $\mathrm{ZnO}$ NPs & $\begin{array}{l}\text { Liquid extraction, } \\
\text { precipitation, and } \\
\text { Hydrometallurgy- }\end{array}$ & 99 & [38-40] \\
\hline $\begin{array}{l}\mathrm{Zn}-\mathrm{MnO}_{2} \\
\text { batteries }\end{array}$ & $\mathrm{Zn}_{\mathrm{x}} \mathrm{Mn}_{1-\mathrm{x}} \mathrm{O}$ NPs & Hydrometallurgy & 57 & [41] \\
\hline $\begin{array}{l}\text { Furnace slag, } \\
\text { Red mud, Fly } \\
\text { ash }\end{array}$ & $\mathrm{TiO}_{2}, \mathrm{SiO}_{2}$ & - & - & [42] \\
\hline Pickling waste & $\mathrm{Fe}_{3} \mathrm{O}_{4} \mathrm{NPs}$ & Co-precipitation & - & [43] \\
\hline $\begin{array}{l}\text { Waste silver } \\
\text { chloride }\end{array}$ & Ag NPs & $\begin{array}{l}\text { Precipitation and } \\
\text { reduction }\end{array}$ & - & [44] \\
\hline
\end{tabular}




\section{Recent categories and strategies of metal oxide recovery}

In the present sub-sections, we discuss a vast range of waste items regenerated and recovered to recuperate precious metals and metal oxides such as electrical machines, batteries, and sludges. As illustrated in Fig. 3, these waste materials can be categorized into three elementary classes, e.g., batteries (Category A), used instruments (Category B), and wastes and sludges (Category C). Several metal nanoparticles, ferrites, and metal oxides could be recovered by recycling these three categories of waste materials using several step methods of solid/liquid spent, as discussed in several literature studies. However, the hydrometallurgical and pyrometallurgical approaches are the most popular processes that yield reusable oxides or ferrites at a considerable quantity. They work on co-precipitation methods and thermal handling. Fig. 4 depicts and summarizes the main steps of the recycling and recovery processes of ultra-pure NPs from combustible wastes such as dry batteries, electronics, etc. using hydrometallurgical or pyrometallurgical approaches. The main fundamentals of those pathways are discussed in the next sections. 


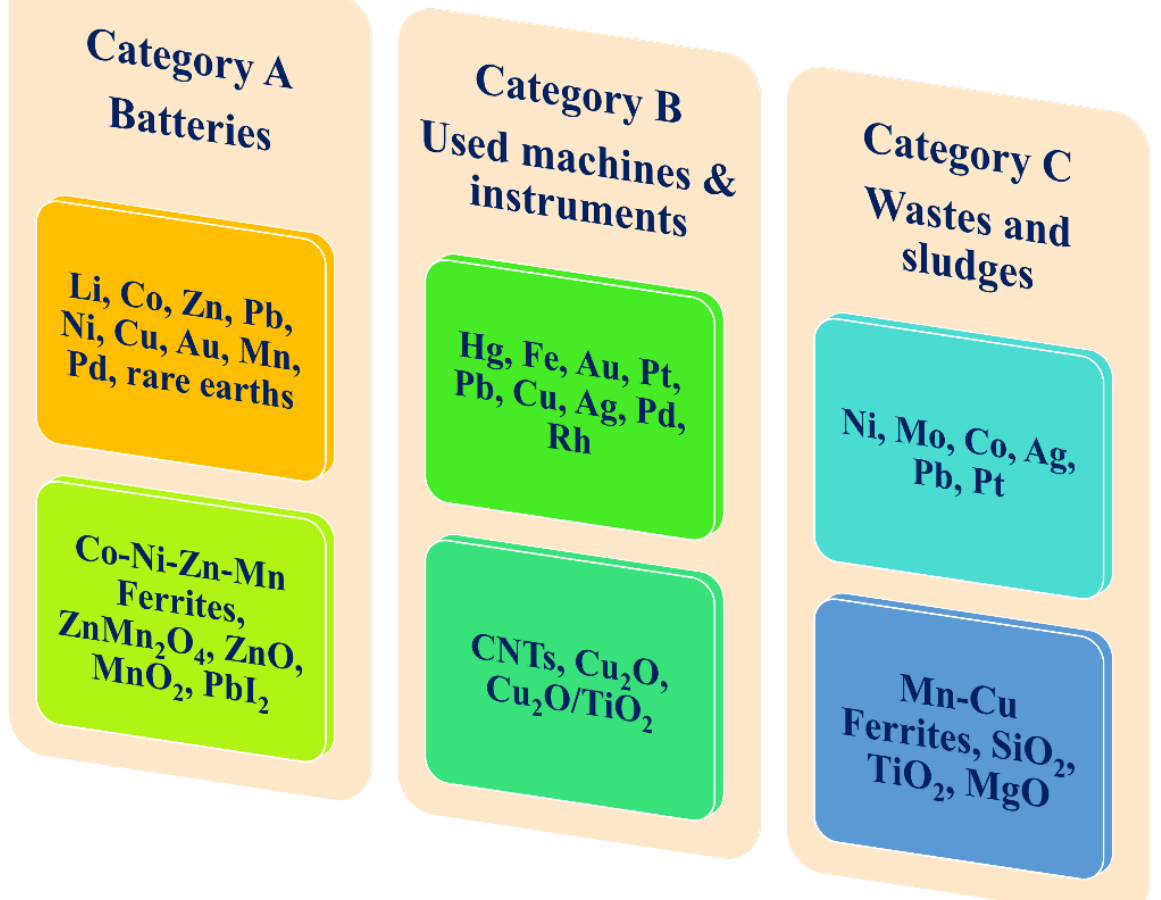

Fig. 3 Categories of recycling and fabrication of nanosized metals oxides and metals from spent/waste.

\subsection{Hydrometallurgical approach pathway}

The hydrometallurgical process is one of the most powerful ways of recycling nanosized metals and metal oxides. As illustrated in Fig. 4, the hydrometallurgical process is divided into several steps, including the dismantlement of the life end products, washing and cleaning with water to uptake all undesirable digestion, alkali/alkaline salts, extraction, thermal treatment, and filtration [45]. The selective leaching of metals could be done in acid (e.g., $\mathrm{HCl}$ and $\mathrm{H}_{2} \mathrm{SO}_{4}$ ) or alkaline (e.g., $\mathrm{NH}_{3} / \mathrm{NaOH}$ ) solutions. Similarly, efficient mineral extraction depends on several parameters such as the acid and base concentration, saturation solubility of the metal, solution $\mathrm{pH}$, and reaction temperature. Furthermore, the effect of oxidants agents (e.g., $\mathrm{H}_{2} \mathrm{O}_{2}, \mathrm{KMnO}_{4}$ ) and reductants agents 
(e.g., citric acid, acidic oxalate, and ascorbic acid) on the selective co-precipitation of metal ions was also inquired [느, 47]. Toro et al. [4] have reported a patented hydrometallurgical method for the large-scale production of the most valuable products using spent alkaline batteries. This method was based on alkaline batteries dissociation to split up fine (mostly manganese, graphite, and zinc) and coarse materials (paper, plastic, and steel), followed by washing and liquidation coprecipitation, cementing, and recrystallization. An agriculture fertilizer such as potassium sulfate was recovered [49]. While the leftover reagents, including acid, reagents, and water, were directed back to leaching's reactor. The residue reagents were regenerated via simple strategies to reduce the wastes generated through the nanomaterial fabrication. In this case study, the reagent solvents utilized to generate the nanomaterials were recycled and used later several times in the same preparation. Several other modern examples of lab-bench scale hydrometallurgical preparation of

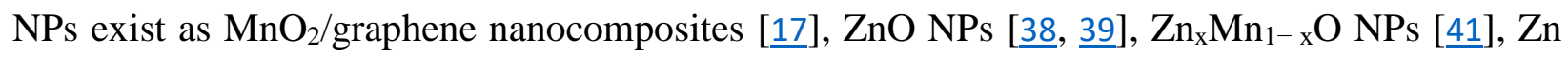
substituted $\mathrm{MnFe}_{2} \mathrm{O}_{4}$ NPs [34], Co-ferrites [34, 37], and Ni-Zn-Mn ferrites [50]. In the hydrometallurgy, we mostly use acid to leach the waste batteries and form soluble salts and then disinfect the product by adjusting the $\mathrm{pH}$, extraction, co-precipitation, etc. [51]. Similarly, some valuable $\mathrm{Zn}$ and $\mathrm{Mn}$ could be extracted from spent $\mathrm{Zn}-\mathrm{Mn}$ batteries using bio-hydrometallurgy, whereas bioleaching bacteria species were used to reduce the extraction time to $24 \mathrm{~h}$ regardless of energy source types [드].

\subsection{Pyrometallurgical approach pathway}

The pyrometallurgical approach pathway is an alternative conventional operation for the recycling and recovering precious metals and metal oxides from the spent electronic equipment wastes. Pyrometallurgical recovery and regenerating operations include mainly the following sequences: 
pyrolysis, reduction, distillation, and incineration [53]. Unlike hydrometallurgy, pyrometallurgical processes need high temperatures to generate metals and metal oxides. For instance, Umicore chemical company (Belgium) could regenerate seventeen different metals from spent electrical and electronic equipment by extracting the metal slags at high temperatures (i.e., $1200{ }^{\circ} \mathrm{C}$ ).

Nevertheless, the formation of toxic or harmful fumes and gases meets a major barrier in the current period [54]. The pyrometallurgy recovery process can be performed under vacuum (i.e., vacuum metallurgy) or different atmospheric pressure (i.e., pressurized metallurgy). Although pressurized metallurgy has been used to recycle and recover zinc oxide from spent waste batteries, it is highly costly due to the latest tail gas treatment equipment. Thus, the vacuum metallurgy recovery process has recently received more attention due to its environmentally friendly advantages [55-60]. Because of the metals lower boiling points during vacuum, metal recycling by vacuum mining reduces energy compared to traditional thermal mining operations (pyrometallurgy processes) [61, $\underline{62]}$.

\subsection{Physical separation approach}

Although wet recycling has attracted complete attention due to its mild reaction conditions, it shows high energy consumption and serious subaltern contamination, limiting its widespread application [주]. Subsequently, low-cost, high-efficiency, and environmentally friendly recovery processes should be considered. Physical separation is an alternative process applied to retrieve useful components from the spent fluorescent lamp, printed circuit board, and batteries. For instance, rare earth phosphorus could be recovered from the spent fluorescent lamps with a recovery efficiency of about 70-90\% by the flotation method [64]. Similarly, polyvinyl chloride (PVC) could be recovered completely (i.e., 100\%) from spent electronic plastics by froth flotation separation after treating the E-waste with $\mathrm{Ca} / \mathrm{CaO}$ composite to hydrophilize the surface of $\mathrm{PVC}$ 
[65]. The electrode materials (e.g., $\mathrm{LiCoO}_{2}$ and graphite) could also be recovered from the spent dry batteries wastes with a recovery rate of $98.99 \%$ via Fenton reagent-assisted flotation [66].

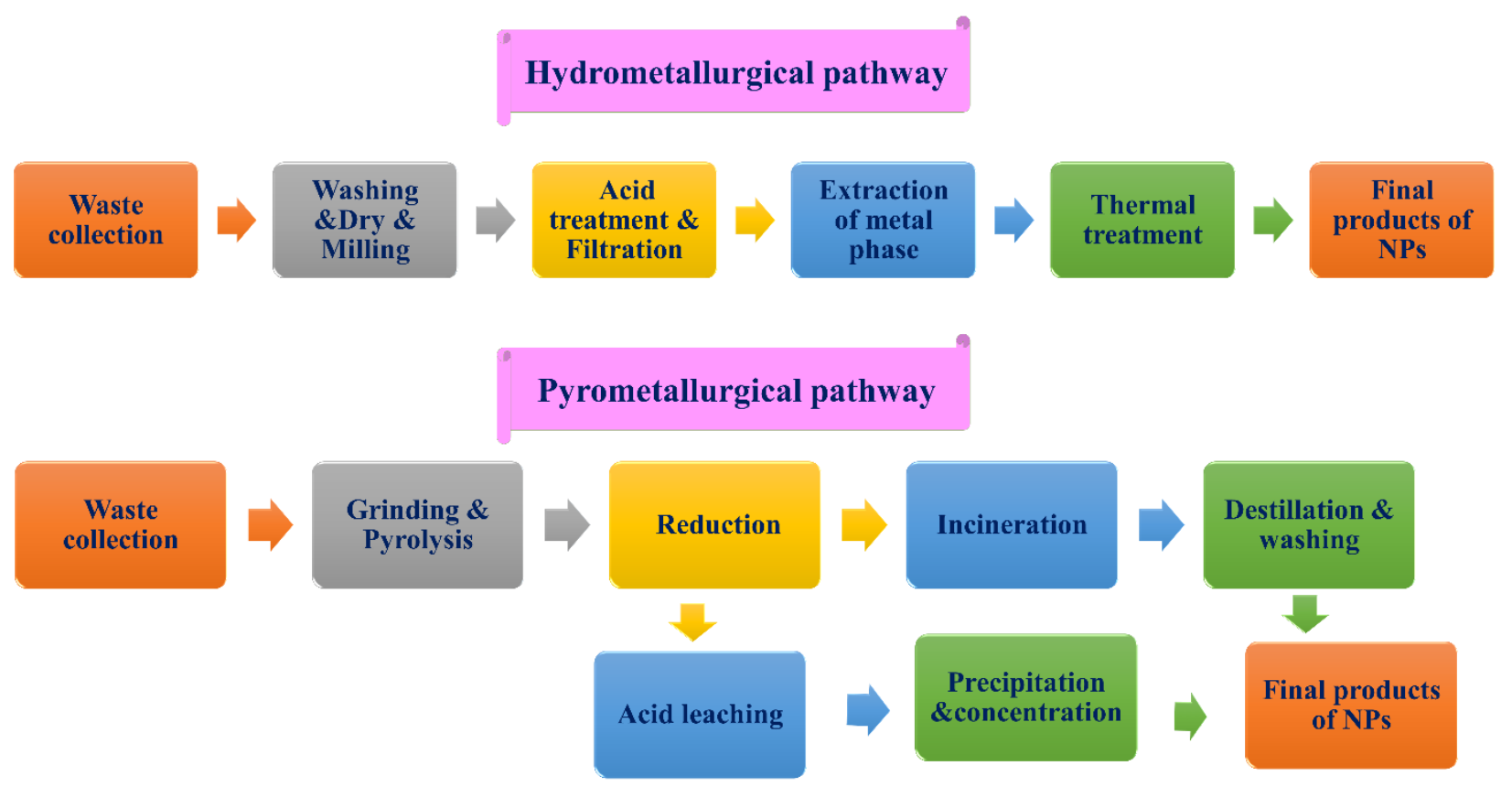

Fig. 4 Strategies of metal oxide recovery from spent/waste.

\section{Recovery of ferrites}

Ferrites are a ceramic-like substance that has magnetic properties useful in many types of electronic devices. Ferrites are iron-based materials, generally gray or black, and exist in a polycrystalline form of many small crystals. Several other transition metals can be present in ferrites materials. For instance, Zn-Mn-Co-ferrites consists of iron oxide and one or more other cations of these transition metals. Magnetic ferrite is widely valued in different fields due to its high electrical resistance, excellent magnetic properties, chemical stability, mechanical rigidity, and relatively low cost; these materials' properties vary significantly from the properties of bulk materials [67-70]. As illustrated in Table 1, the recycling and recovery of ferrites NPs from the spent wastes started in the last decade, approximately in 2004. Xi et al. are among the pioneering groups that established $\mathrm{Zn}-\mathrm{Mn}$ magnetic ferrite NPs recovery from dry $\mathrm{Zn}-\mathrm{MnO}_{2}$ batteries after 
end life via co-precipitation process [71]. They found that the recovery process could be affected by several factors, such as co-precipitation $\mathrm{pH}$ and temperature of co-precipitation and calcination processes. Their studies showed that Zn-Mn magnetic ferrite NPs could be appropriately recovered using a co-precipitation $\mathrm{pH}$ of about $7.0-7.5$ at $50^{\circ} \mathrm{C}$ and calcination temperatures between 1100 $-1150{ }^{\circ} \mathrm{C}$. As illustrated in Fig. 5, magnetic manganese ferrite $\left(\mathrm{MnFe}_{2} \mathrm{O}_{4}\right)$ could be successfully synthesized from manganese solution recycled and recovered by leaching the cathode material of spent wastes of zinc-manganese oxide batteries with $0.5 \mathrm{~mol} / \mathrm{L}$ nitric acid and $30 \%(\mathrm{v} / \mathrm{v}) \mathrm{H}_{2} \mathrm{O}_{2}$ at $80{ }^{\circ} \mathrm{C}$, followed by reaction with ferric chloride and calcination of obtained coprecipitate at 450 ${ }^{\circ} \mathrm{C}$ [16]. The obtained $\mathrm{MnFe}_{2} \mathrm{O}_{4}$ materials were a promising catalyst for heterogeneous photoFenton photodegradation of methylene blue dye, which accomplished $92 \%$ dye decolorization within 120 min irradiation [16]. 
(a)

$$
\begin{aligned}
& \mathrm{MnO}_{2(\mathrm{~s})}+2 \mathrm{HNO}_{3(\mathrm{aq})}+\mathrm{H}_{2} \mathrm{O}_{(\mathrm{l})} \rightarrow \mathrm{Mn}\left(\mathrm{NO}_{3}\right)_{2(\mathrm{aq})}+2 \mathrm{H}_{2} \mathrm{O}_{(\mathrm{l})}+\mathrm{O}_{2(\mathrm{~g})} \\
& \mathrm{Mn}_{3} \mathrm{O}_{4(\mathrm{~s})}+6 \mathrm{HNO}_{3(\mathrm{aq})}+\mathrm{H}_{2} \mathrm{O}_{2(\mathrm{l})} 3 \mathrm{Mn}\left(\mathrm{NO}_{3}\right)_{2(\mathrm{aq})}+3 \mathrm{H}_{2} \mathrm{O}_{(\mathrm{l})}+3 / 2 \mathrm{O}_{2(\mathrm{~g})}
\end{aligned}
$$

$\mathrm{FeCl}_{3}$

$\mathrm{MnFe}\left(\mathrm{H}_{2} \mathrm{O}\right)_{6(\mathrm{aq})}^{3+}+3 \mathrm{NH}_{3} \leftrightarrows \mathrm{MnFe}\left(\mathrm{H}_{2} \mathrm{O}\right)_{3}(\mathrm{OH})_{3(\mathrm{~s})}+3 \mathrm{NH}_{4}^{+}$

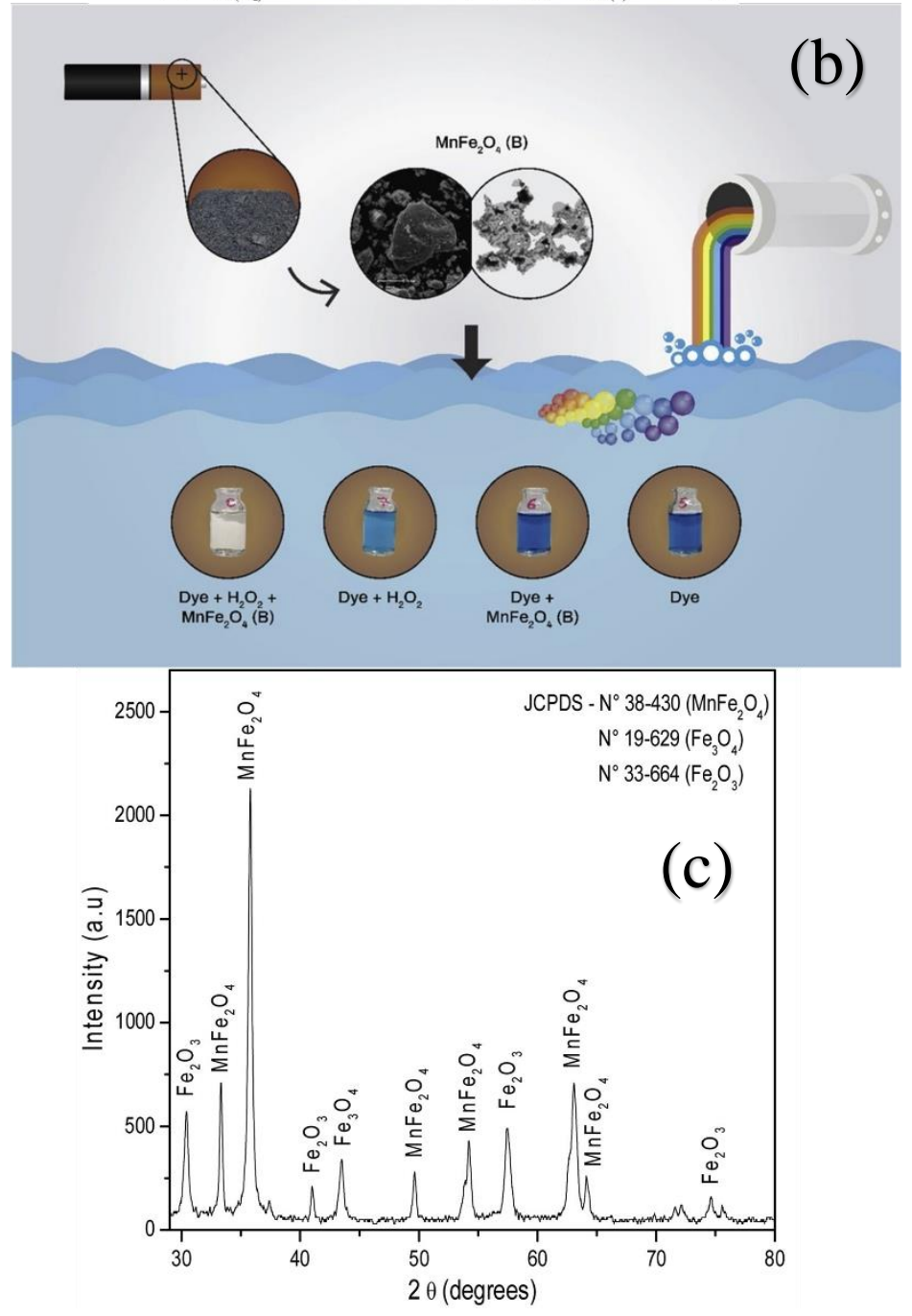

Fig. 5 (a) The equation mechanis of $\mathrm{MnFe}_{2} \mathrm{O}_{4}$ recovery via leaching the electrode material of spent zinc-manganese oxide batteries with nitric acid. (b) Schematic representation of effieciency of $\mathrm{MnFe}_{2} \mathrm{O}_{4}$ for water remidation. (c) X-ray diffractogram of $\mathrm{MnFe}_{2} \mathrm{O}_{4}$ synthesized from spent batteries. Adapted with permission from Ref. [16] (Copyright 2020, Elsevier). 
Chang-hong et al. [72] have reported the synthesis of Mn-Zn light magnetic ferrite NPs from the waste of $\mathrm{Zn}-\mathrm{Mn}$ batteries (e.g., spent scrap iron and pyrolusite $\mathrm{MnO}_{2}$ ) via leaching, purification, and co-precipitation processes. In the first step, the leaching of the spent materials in $\mathrm{H}_{2} \mathrm{SO}_{4}$ has yielded about $92.02,96.14$, and $98.34 \%$ of Fe, $\mathrm{Mn}$, and $\mathrm{Zn}$, respectively. They have then washed the leached solutions with ammonia, ammonium sulfhydrate, and ammonium sulfide to remove the heavy metals, $\mathrm{Ca}^{2+}$ and $\mathrm{Mg}^{2+}$ by vulcanized and fluorination precipitations (i.e., double salt precipitation deep purification). This deep purification process has led to high removal efficiencies of most of the impurities. For instance, 99.7, 96.5, 92.3, 63.6, 99.9, 53.0, and 78.7\% of $\mathrm{Ca}, \mathrm{Al}$, $\mathrm{Mg}, \mathrm{Si}, \mathrm{Cu}, \mathrm{Cd}$, and $\mathrm{Ni}$, respectively, have been removed after the purification process. Thus, the obtained $\mathrm{Mn}-\mathrm{Zn}$ soft magnetic ferrite powders after the co-precipitation process have been found to contain $\mathrm{Zn} 4.49 \%$, Mn $13.92 \%$, and $\mathrm{Fe} 41.41 \%$ with the mass ratio of $\mathrm{Mn}: \mathrm{Zn}$ :Fe equals to 7.5:23.3:69.2 (theoretical mass ratio $\mathrm{Zn}: \mathrm{Mn}: \mathrm{Fe}=8.3: 24.4: 67.3$ ). The low content of impurities in recovered Mn-Zn soft magnetic ferrite made them better than the synthetic PC30 produced by the Japanese TDK company [72]. Nan et al. [33] have also fabricated Zn-Mn ferrites from the spent Mn-Zn batteries by chemical co-precipitation using ammonium oxalate. They first dismantled spent zinc manganese dioxide batteries with a mechanical machine. The dismantling materials were watered, and the iron battery components were collected using a magnet, and the remaining residual materials were baked and griddled to obtain zinc and manganese species. The separated Fe-, Zn- and Mn-species were dissolved in $\mathrm{H}_{2} \mathrm{SO}_{4}$ to obtain $\mathrm{FeSO}_{4}, \mathrm{ZnSO}_{4}$, and $\mathrm{MnSO}_{4}$ solution, respectively, that were used in the synthesis of $\mathrm{Zn}-\mathrm{Mn}$ ferrite magnetic materials with the composition of $\mathrm{Mn}_{0.26} \mathrm{Zn}{ }_{0.24} \mathrm{FeO}_{2}$ after the calcination of the co-precipitated precursor at 850 $1250^{\circ} \mathrm{C}[33]$. Xi et al. [15] have fabricated nanocrystalline ferrites from the spent alkaline $\mathrm{Zn}-\mathrm{Mn}$ batteries using sol-gel and combustion methods. The gel containing Fe, Mn, and $\mathrm{Zn}$ cations was 
first prepared by dissolving the spent battery materials in an $\mathrm{HNO}_{3}$ solution containing $2.5 \mathrm{wt} . \%$ $\mathrm{H}_{2} \mathrm{O}_{2}$, followed by the addition of citric acid and ammonia and drying at $135^{\circ} \mathrm{C}$ for $2 \mathrm{~h}$. The XRD, TGA, DTA, SEM, ICP, and FTIR characterizations showed that the dried gels are self-propagating combustion led to the nanocrystalline formation of manganese zinc ferrites with the stoichiometry $\mathrm{MnZn}_{0.85} \mathrm{Fe}_{2} \mathrm{O}_{4}$ [15]. However, it is worth mentioning that they have used analytical grade manganese nitrate, zinc nitrate, and iron nitrates to adjust the concentration of $\mathrm{Mn}, \mathrm{Zn}$, and Fe to obtain this stoichiometric spinel.

Similarly, Mylarappa et al. [14] have also prepared nanocrystalline zinc-manganese ferrites from the spent $\mathrm{Zn}-\mathrm{C}$ batteries as raw materials by dissolution in $\mathrm{H}_{2} \mathrm{SO}_{4}$ followed by co-precipitation in $\mathrm{NaOH}$ at $100{ }^{\circ} \mathrm{C}$. They used the obtained zinc-manganese ferrites to decorate rGO by using a solvothermal route. Their GO/Mn-Zn ferrite nanocomposite showed excellent photoactivity performance to decompose acid orange 88 dye in wastewater under ultraviolet irradiated, as illustrated in Fig. 6 [14]. 


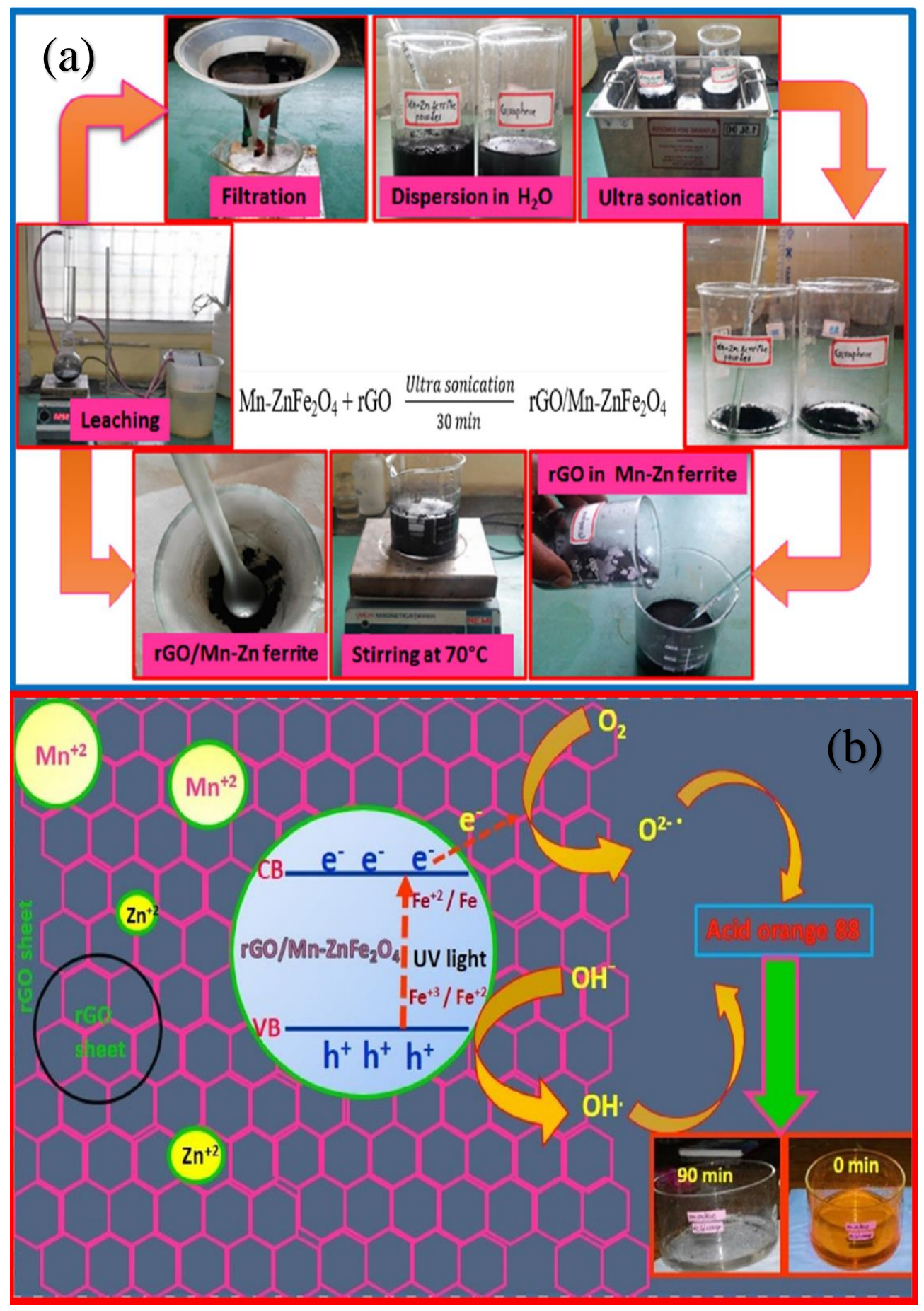

Fig. 6 (a) Schematic representation of recovery of nanosized Mn-Zn ferrites using Zn-C dry batteries. (b) The mechanism of acid orange 88 decomposition for $\mathrm{Mn}-\mathrm{Zn}$ ferrite-rGO nanocomposite. Adapted with permission from Ref. [14] (Copyright 2019, Elsevier). 
Several harmful byproducts can be produced in the stainless-steel industries, such as fly ash and ultrafine particle, which can easily bioaccumulate leak and snuff, and pose a critical menace to the humans and environment of the world [73-76]. Magnetic ferrites have also been recovered and purified from industrial fly ash wastes. The magnetic ferrites (e.g., $\gamma-\mathrm{Fe}_{2} \mathrm{O}_{3}$ and $\mathrm{Fe}_{3} \mathrm{O}_{4}$ ) from fly ash waste depend on the interactions between magnetic ferrites with the applied magnetic field [75]. Lin et al. have utilized a magnetic separator to separate magnetic Ni-ferrites NPs from a steel industrial fly ash (RFSIF) with a good separation factor of 74\%. These Ni-ferrites NPs were found suitable for various applications, especially as a catalyst for the hydrolysis and methanation of $\mathrm{CO}_{2}$ using fluid hydrogen gas, as shown in Fig. 7 [77].

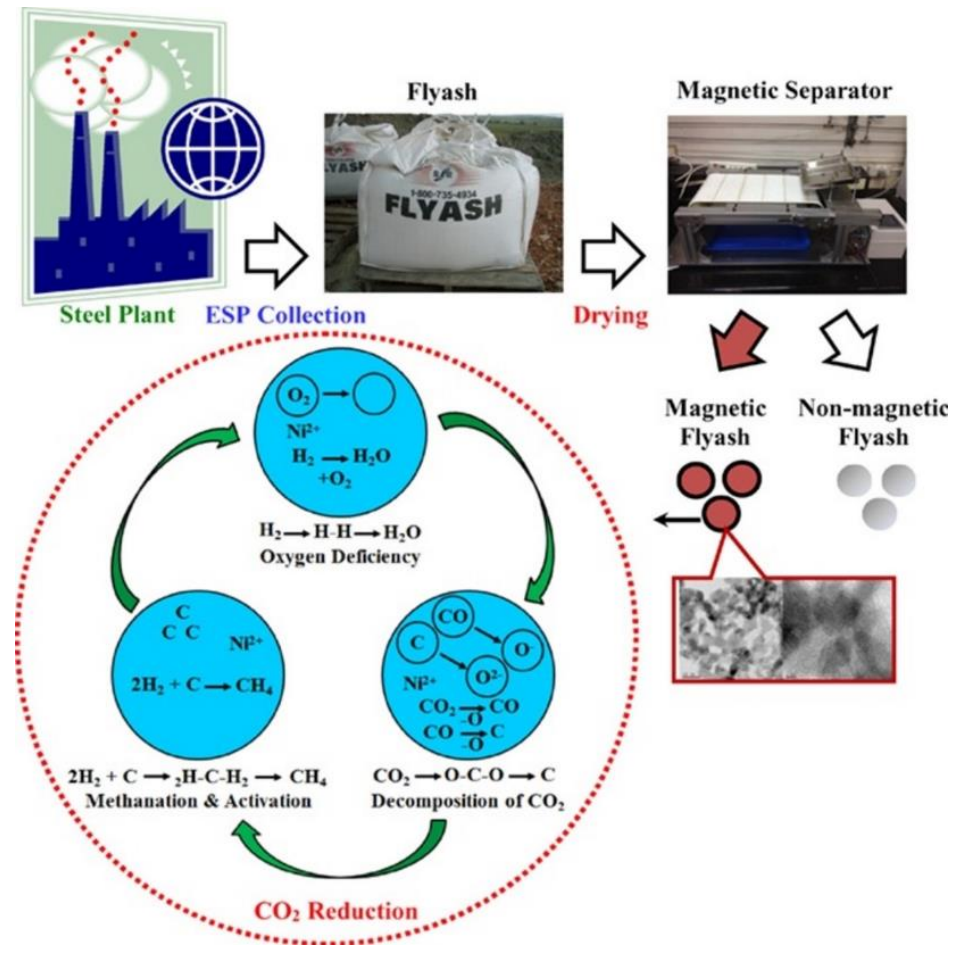

Fig. 7 Recovery of magnetic ferrite from fly ash for decomposition/methanation of $\mathrm{CO}_{2}$. Adapted with permission from Ref. [77] (Copyright 2018, Elsevier). 
Magnetic cobalt-ferrites are another class of ferrites materials with distinct chemical, physical and mechanical properties $[\underline{37}, \underline{78}, \underline{79}]$. For instance, they typically demonstrate a low-frequency magnetic permeability and a high magnetic polarization angle in visible light at ambient temperature $[\underline{37}, \underline{78}, \underline{79}]$. Cobalt-ferrite also has excellent chemical consistency and high wear resistance to corrosion [80]. Magnetic cobalt ferrites have also been applied as a microwave absorber [81]. As shown in Fig. 8, spinel cobalt ferrites, NPs with the composition of $\mathrm{Co}_{0.8} \mathrm{Fe}_{2.2} \mathrm{O}_{4}$, have been fabricated from the spent cathode of lithium-ion batteries as raw materials by sol-gel route using ethylene glycol as a gelling agent [37]. TEM, XRD, XPS, FTIR, SEM, and VSM characterizations showed that the synthesis parameters could influence the cobalt ferrites' chemical structure, morphology, and magnetic properties. Spinel $\mathrm{Co}_{0.8} \mathrm{Fe}_{2.2} \mathrm{O}_{4}$ NPs with a saturated magnetization of around $61.96 \mathrm{emu} . \mathrm{g} / \mathrm{L}$ could be obtained at the optimum synthesis parameters of metal ion to ethylene glycol ratio $\sim 1: 0.8$, annealing temperature $\sim 800^{\circ} \mathrm{C}$, and the annealing time about $6 \mathrm{~h}$ [37]. 


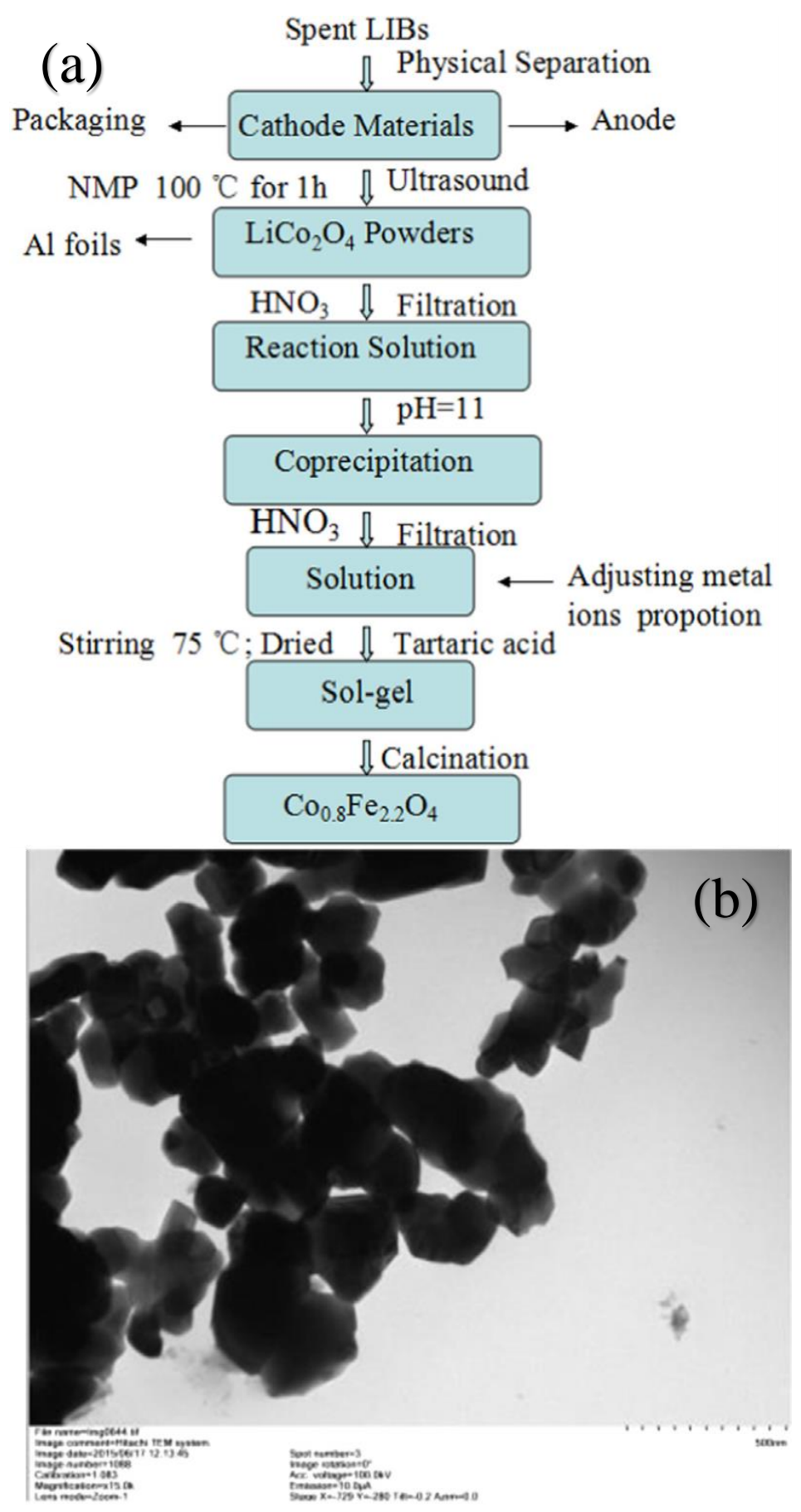

Fig. 8 (a) Schematic chart of magnetic cobalt-ferrite spinel prepared from spent Li-ion batteries. (b) TEM analysis of the magnetic cobalt-ferrite spinel elaporated from Li-ion batteries. Adapted with permission from Ref. [37] (Copyright 2016, Elsevier). 


\section{Recovery of zinc oxide}

$\mathrm{ZnO}$ has shown remarkable implementation prospects in treating environmental contamination, particularly in organic wastewater remediation [82]. Researchers worldwide have proposed different recovery methods of $\mathrm{Zn}$-based materials, which can mainly be divided into pyrometallurgy and hydrometallurgy. In China, about $373 \mathrm{Gg}$ of $\mathrm{ZnO}$ have been utilized to manufacture batteries in 2003 and have increased to $535 \mathrm{Gg}$ in 2005 [83]. NPs could be effectivelyprepared from the spent $\mathrm{Zn}-\mathrm{Mn}$ dry batteries by high-temperature evaporation-separation and oxygen control oxidation using air as both carrier gas and oxidizer [84]. Although carbon powder or lead powder were used as additional materials to isolate the oxygen, zinc's oxidation rate was still fast. However, $\mathrm{Zn}$ could be first evaporated and recovered from the zinc hull covered with fiber mat with a recovery efficiency of $\sim 98.99 \%$ and then oxidized into nanotetrapod $\mathrm{ZnO}$ by using a heating temperature of $1123 \mathrm{~K}$, air pressure of $3 \mathrm{kPa}$, and blowing airflow at $723 \mathrm{~K}$ [84]. Nevertheless, due to the unstable content and flow rate of oxygen, the morphology of the substance obtained in this way is not standardized. $\mathrm{ZnO}$ NPs with variable morphologies have been obtained from the spent $\mathrm{Zn}-\mathrm{Mn}$ battery by vacuum evaporation and oxygen control method [85]. In this method, the morphology of $\mathrm{ZnO}$ NPs could be controlled by adjusting the flow rate of the $\mathrm{N}_{2}$ conveyor, the content of $\mathrm{O}_{2}$ oxidizer, calcination temperature, used substrate, and condensing distance. For instance, nanotetrapod $\mathrm{ZnO}$ photocatalyst could be formed on a glass plate at 1123 $\mathrm{K}$ under $12.5 \%$ oxygen content and a nitrogen flow rate of $21 \mathrm{Lmin}^{-1}$ [85]. 


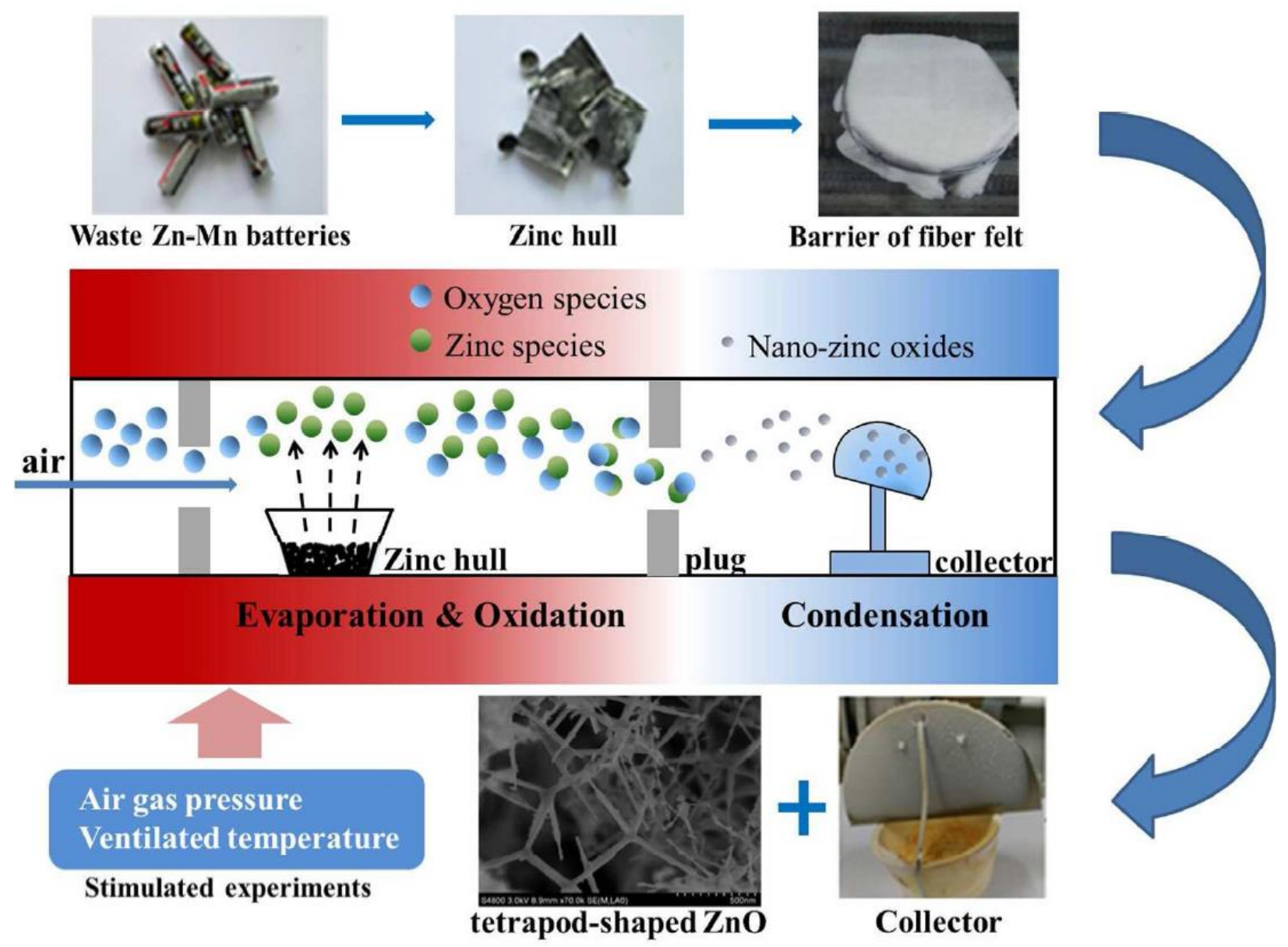

Fig. 9 Recovery of zinc oxide by high-temperature evaporation-separation and oxygen control oxidation. Adapted with permission from Ref. [84] (Copyright 2018, American Chemical Society).

Deep and his co-worker [39] have recently proposed a novel and easy method for the recovery of highly-pure ZnO NPs from the electrode waste of spent alkaline zinc-manganese oxide batteries. The spent electrode materials were gathered using manual disassembly and mixed with $5 \mathrm{M} \mathrm{HCl}$ to interact with the phosphine oxide reagent $\mathrm{Cyanex} 923^{\circledR}$ at $250^{\circ} \mathrm{C}$ for $30 \mathrm{~min}$ to form $\mathrm{Zn}$-Cyanex 923 complex, as illustrated in Fig. 10. With approximately $5 \mathrm{~nm}$ diameter, ZnO NPs were then 
prepared from the Zn-Cyanex 923 complex by an ethanolic precipitation process. Therefore, the proposed process provides an easy and efficient way to regenerate ultra-pure ZnO NPs from the spent dry waste batteries compared with other high-temperature evaporation-separation techniques oxygen control oxidation.

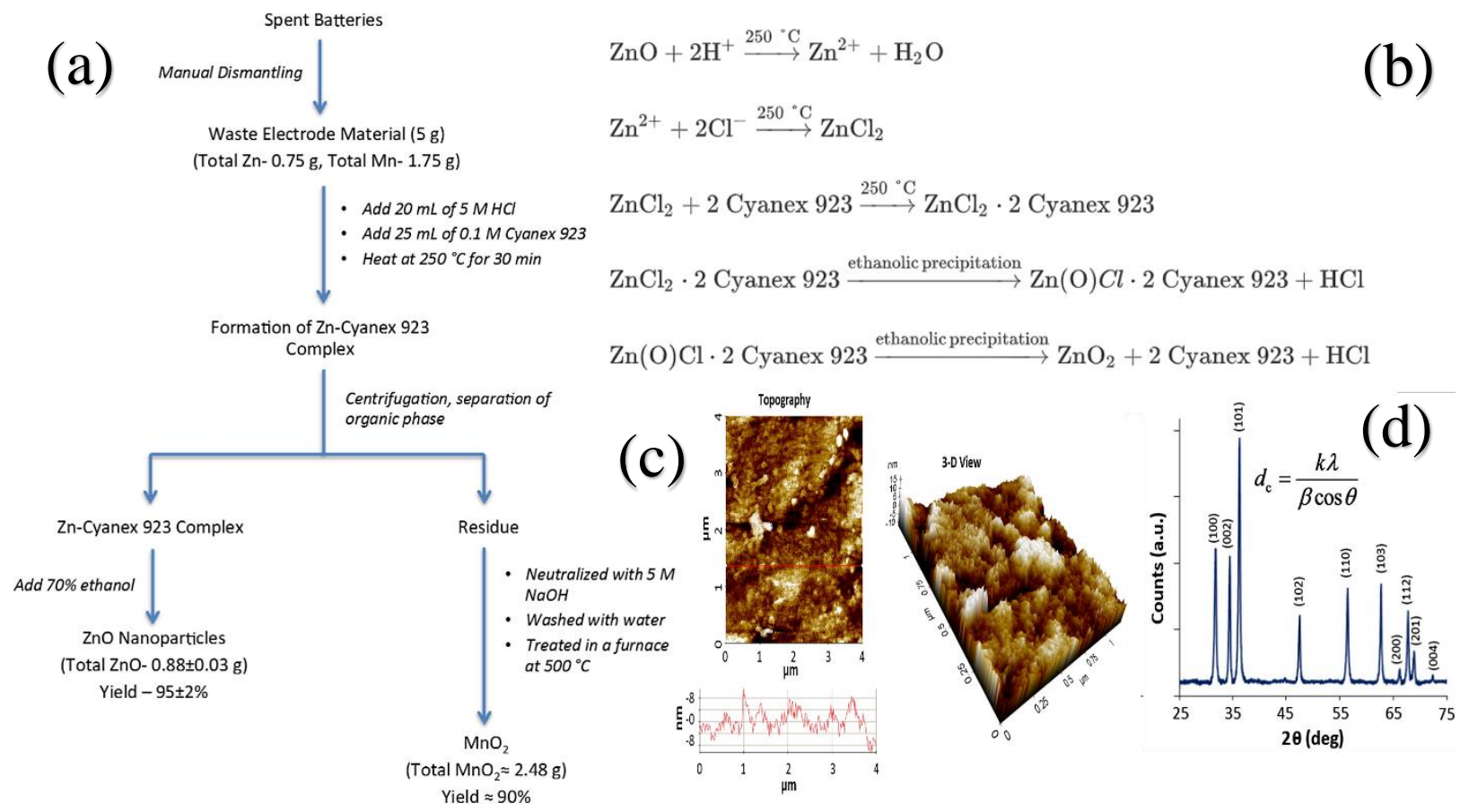

Fig. 10 (a) Schematic flowchart of $\mathrm{ZnO}$ nanoparticles recovery from spent alkaline batteries. (b) The equation mechanis of $\mathrm{ZnO}$ nanoparticles recovery. (c) AFM topography, line analysis, and 3$\mathrm{D}$ view of the recovered $\mathrm{ZnO}$ nanoparticles. (d) XRD analysis of the recovered $\mathrm{ZnO}$ nanoparticles.s Adapted with permission from Ref. [86] (Copyright 2018, CNKI).

\section{Recovery of indium tin oxide}

Recently, the world's indium reserves are around 12,000-13,000 tons, representing only $1 / 6$ of the

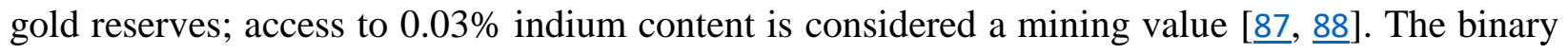


and ternary indium oxides have recently attracted much scientific and technological interest among indium compounds due to their fascinating structural chemistry and promising functionalities [8992]. Indium-based materials are widely applied in radioelectronic, spintronic, and semiconductor manufacturing processes due to its special electrical, chemical, and physical properties [93-95]. Thus, it is considered an essential strategic resource in recent industrial growth [96]. More than $80 \%$ of extracted indium in the world is employed in the fabrication of indium tin oxide (ITO) materials [97] that contain more than 90\% indium oxide and less than $10 \%$ tin oxide [98]. ITO is widely used to fabricate the touch display of smartphones and liquid crystal display panels (LCD) [99]. Thus, the amount of indium in the world is reduced with time, and it is getting expansive due to its scarcity on the earth [100]. The recovery of indium from the wastes of LCD devices should be urgently regulated [101].

As illustrated in Fig. 11, the board of LCD consists of two polarizing films, two glasses substrate covered by the ITO layer, a color filter film, and a liquid crystal band. Because of the large indium content in an ITO film, the waste LCD is considered a potential secondary source of indium [102]. However, the recovery of In from LCD screens faces some problems due to the harmful impurities and components in the display (e.g., liquid crystals, plastics, and mercury) that can be released during the dismantling process of the LCD [103]. To date, most of the studies on the recovery of indium from waste LCD panels focused on the aqueous hydrometallurgical pathway. For instance, Li and his co-workers [104] have reported the recovery of indium from the waste LCD screens using a multi-step process, including the removal of LCD polarizing film and liquid crystals by thermal shock at $230-240{ }^{\circ} \mathrm{C}$ and the ultrasonic cleaning at $40 \mathrm{KHz}$, respectively, and the recovery of indium from ITO glass by acid dissolution. This multi-step process led to the recovery of $92 \mathrm{wt} \%$ of indium metal when a solution mixture of $\mathrm{HCl}$ and $\mathrm{HNO}_{3}$ acids with the 
ratio of $\mathrm{HCl}: \mathrm{HNO}_{3}: \mathrm{H}_{2} \mathrm{O}=45: 5: 50$, and aging temperature and time of $60{ }^{\circ} \mathrm{C}$ and $30 \mathrm{~min}$, respectively, are used. Lee et al. [105] have reported that the particle size of ITO materials crushed by high energy ball milling and the amount of $\mathrm{HCl}$ in the acidic solution could strongly affect the recovery efficiency of indium from the waste LCD panels. They could rapidly recover $86 \%$ of the indium in the waste materials after $1 \mathrm{~min}$ of ball milling using the acid solution $\left(\mathrm{HCl}: \mathrm{H}_{2} \mathrm{O}=50: 50\right)$. Solvent extraction, which is based on sulphuric acid leaching, di(2-ethylhexyl)phosphoric acid extraction, and $\mathrm{HCl}$ back extraction, is another alternative approach to recover indium from thinfilm-transistor liquid-crystal display (TFT-LCDs) waste [106] $\{$ Bekheet, 2013 \#89\}. In this method, $97 \%$ of indium in the raw materials could be recovered by leaching the waste materials $\mathrm{H}_{2} \mathrm{SO}_{4}(1: 1$, v/v) acid solution, followed by two extraction process using $30 \%$ of $\operatorname{di}(2-$ ethylhexyl)phosphoric acid solution $(\mathrm{O} / \mathrm{A}=1: 5)$ for $5 \mathrm{~min}$, and $4 \mathrm{M} \mathrm{HCl}$ acid solution. Hsieh and his co-worker [107] have reported the recovery of highly pure sponge indium (>99\%) from spent ITO waste using hydrometallurgical in 30 vol.\% $\mathrm{HCl}$ solution at $80{ }^{\circ} \mathrm{C}$ for $30 \mathrm{~min}$, followed by hot immersion in $\mathrm{KOH}$ solution at $300{ }^{\circ} \mathrm{C}$ for $10 \mathrm{~min}$.

In addition to the hydrometallurgical method, chlorination, vacuum carbon reduction, sub-critical water have also been applied to recover indium from ITO waste. For instance, Ma and Xu [108] have recovered $99.97 \%$ of indium in the ITO waste as indium chloride by using vacuum pyrolysis at $300{ }^{\circ} \mathrm{C}$ and $50 \mathrm{~Pa}$ to separate oil and organic materials, followed by vacuum chlorinated separation using $50 \mathrm{wt} \% \mathrm{NH}_{4} \mathrm{Cl}$ at $450{ }^{\circ} \mathrm{C}$. Similarly, 66.7 and $54.1 \%$ of indium could be recovered from LCD waste in the form of indium chloride by chloride volatilization process under air and $\mathrm{N}_{2}$, respectively, using polyvinyl chloride (PVC) as chlorine agent at $350{ }^{\circ} \mathrm{C}$ and a $\mathrm{Cl} / \mathrm{In}$ a molar ratio of 11 [109]. Zhang and his co-worker [110] could also prepare indium chloride with 36\% of indium from waste LCD panels containing $0.02 \mathrm{wt} \%$ in a multi-step process including mechanical 
stripping, a series of pyrolysis separation, chlorinated vacuum separation, and substitution reaction. He et al. [111] have reported that $90 \mathrm{wt} \%$ of indium could be recovered from waste LCD panel by vacuum carbon-reduction using $30 \mathrm{wt} \%$ carbon as additives at $1223 \mathrm{~K}$ and $1 \mathrm{~Pa}$ for 30 minutes. Yoshida et al. [112] have demonstrated that 83 and $10 \%$ of indium could be recovered from stained glass (CF) and TFT glass of LCD waste, respectively, using semi-critical water $360{ }^{\circ} \mathrm{C}$. They also found that $\mathrm{NaOH}$ 's addition during the recovery process could increase the recovery efficiency of indium from both CF and TFT glasses to 99 and $95 \%$, respectively, at $220{ }^{\circ} \mathrm{C}$ after 5 min. Indium could also be recovered as $\operatorname{In}^{3+}$ ions from LCD waste via the microbial adsorption method, whereas a gram-negative bacterium could adsorb $\operatorname{In}^{3+}$ ions generated by leaching the spent $\mathrm{LCD}$ panel in $\mathrm{HCl}$ solution under hydrothermal conditions $\left(120^{\circ} \mathrm{C}, 0.198 \mathrm{MPa}\right.$, $5 \min )[113]$.

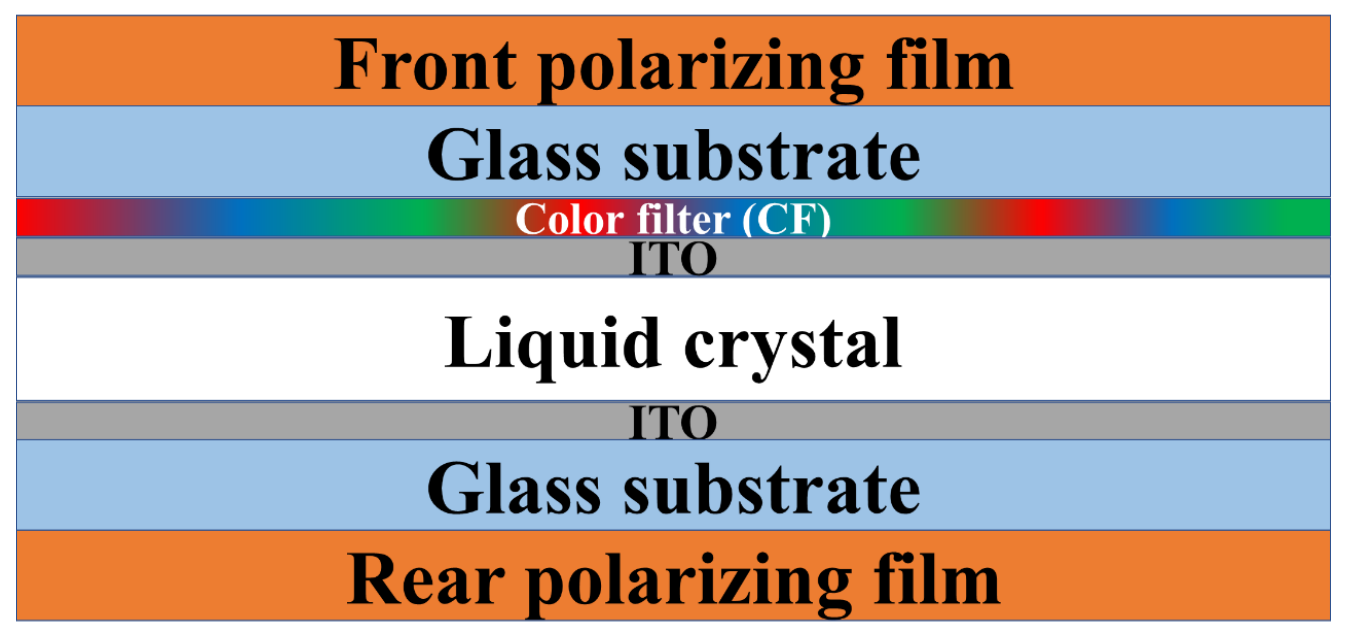

Fig. 11 The configuration of the LCD panel.

Even if indium tin oxide is the target, the CF glass is the primary medium because ITO adheres to the $\mathrm{CF}$, easily removed by crushing from the glass (Figure 11). The flotation process has also been 
utilized to recover ITO from color filter (CF) glass in waste LCD panels, as illustrated in Figure 12 [114]. ITO could be easily separated from glass for indium recycling by the floatability of CF due to its hydrophobicity caused by hydrophobic methyl groups and aromatic ring. The separation of CF containing ITO from the glass substrate was found to depend on the feed size of crushed materials, and the recovery of indium and ITO increased with decreasing feed size. For instance, $85.21 \%$ of ITO containing $0.61 \%$ indium could be recovered for particles with a size smaller than $0.025 \mathrm{~mm}$. In addition, the indium oxide concentration and the recovery of indium tin oxide increased with increasing grinding time. The $92.51 \%$ of ITO containing $0.60 \%$ indium was recovered after 80 minutes of milling.

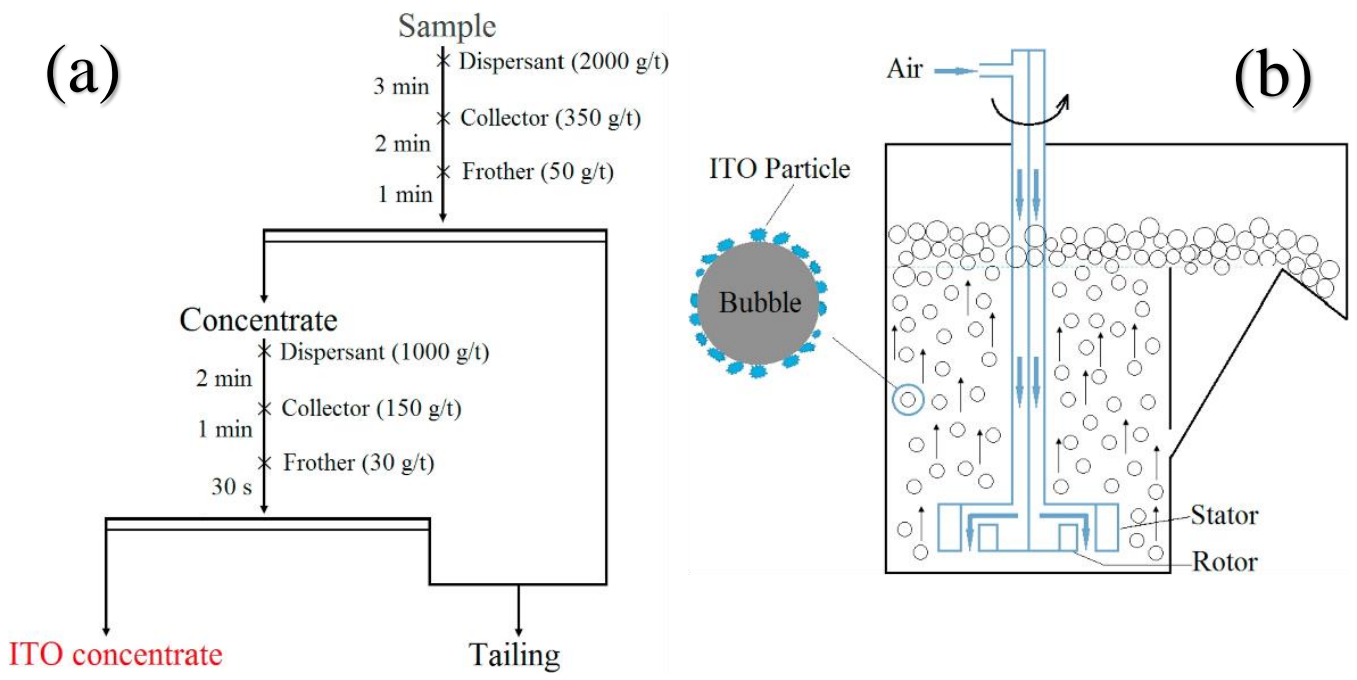

Fig. 12 (a) Flowsheet of ITO recovery by flotation. (b) Schematic diagram for ITO and glass separation by flotation. Adapted with permission from Ref. [114] (Copyright 2018, Elsevier).

Thermal decomposition is another approach that has been applied to recover ITO from the waste color filter (CF) glass, as illustrated in Fig. 13 [115]. The ITO layer could be first separated from the glass substrate after the color layer's thermal oxidation. Although the yield of recovered ITO 
was found to decrease with increasing temperature and time of the thermolysis process, the recovery and enrichment ratio was increased. After thermolysis at $600{ }^{\circ} \mathrm{C}$ for $8 \mathrm{~min}, 98 \%$ of ITO could be efficiently recovered with yield and enrichment ratio of $0.06 \%$ and 1669 , respectively. Moreover, the crystal structure of recovered ITO has not been changed during the thermolysis process. It is worth noting that the authors have used activated carbon during thermolysis to adsorb the released toxic mixed flue gas that might harm the atmospheric environment [115].

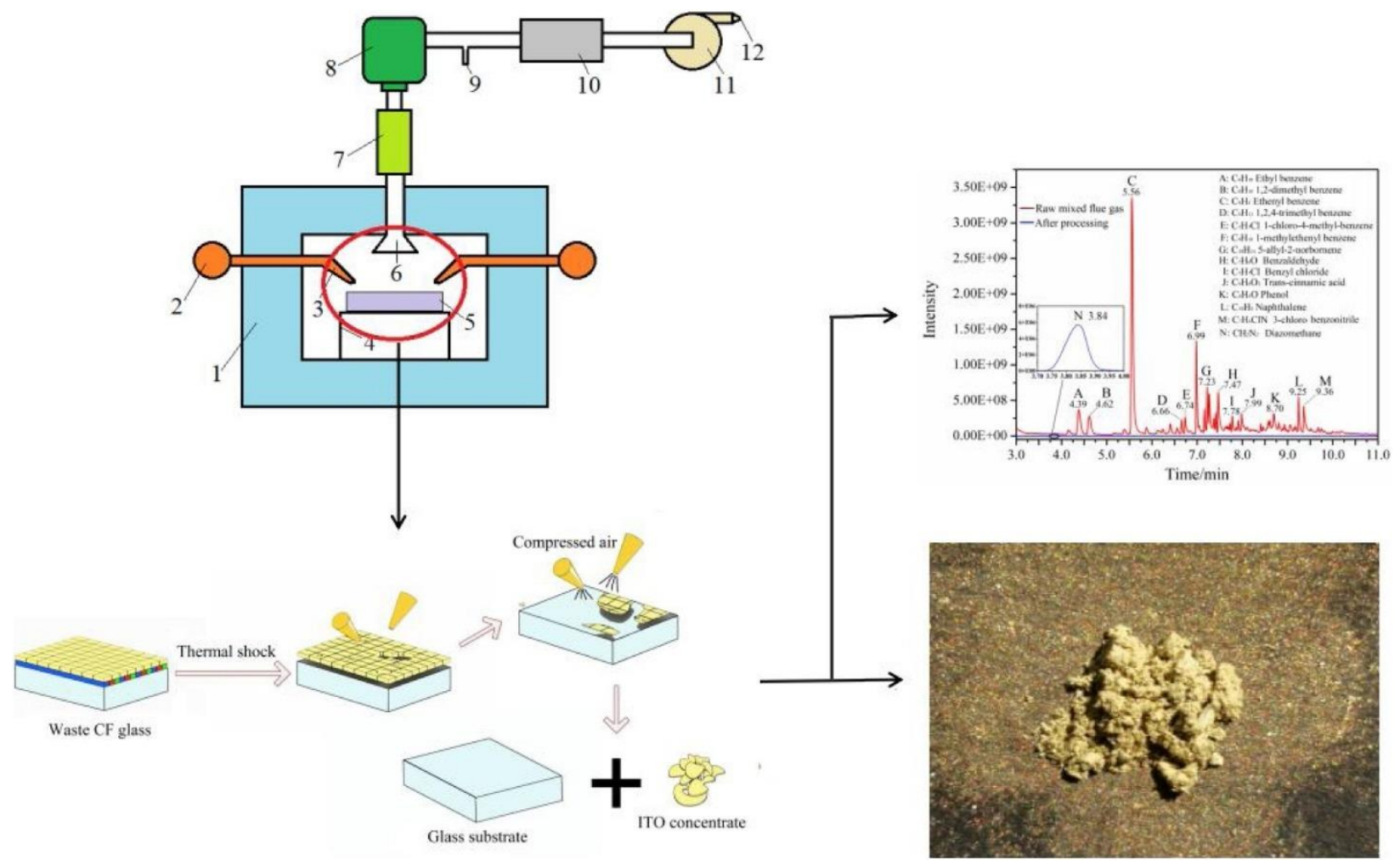

Fig. 13 Recovery of ITO by thermal decomposition of waste color filter glass. Adapted with permission from Ref. [115] (Copyright 2020, Elsevier).

\section{Conclusions}

There is no dispute concerning the significance of recycling spent waste and the recovery and regeneration of high-value products, including minerals, nanoparticles, and other materials. 
Nevertheless, the literature in this work remains to be explained inappropriate technology due to the limitation of cost-effectiveness. Moreover, although recycling is beneficial from an environmental point of view, economic sustainability cannot often be achieved for an advanced process without subsidizing the country due to low or non-existent profits. However, new methods appear more favorable, perhaps for modern trade models to become more profitable than debris. With the scheme increasing by $21 \%$ annually in global depletion of metal oxides by 2019 , there is a critical need to generate potential metal oxide supplies. Conventional processes for converting bulk materials into metal oxides (NPs) can increase supply slightly. Recycling such materials from recycled expenses thus opens up the possibility that some of the most important materials will create a secondary supply chain. Overall, we have found that most of the currently available recycling technologies need more refinement to produce finished commercial goods.

\section{Future prospective}

Furthermore, the reproduction of specific recovery methods and stability should be dealt with more widely. Reuse of materials that have been produced or degraded after application for various treatment purposes is crucial, especially as production costs for NPs with high-purity metal oxides are generally high. The replication and degradability or reuse of recycled metal oxides should be given greater importance to close existing research gaps. For the nanostructures to survive, a systematic approach is also required to determine risks associated with the use and disposal of the major metal oxides associated with the product. The evolution of the process for assessing toxicity that predicts potential impacts on human health and the environment is still critical. Finally, applying a green process may significantly raise the benefits of pilot projects, and it should be taken into consideration. 


\section{References}

1. Al-Salem SM, Lettieri P, and Baeyens J (2009) Recycling and recovery routes of plastic solid waste (PSW): A review. Waste Management 29(10):2625-2643

2. Ordoñez J, Gago EJ, and Girard A (2016) Processes and technologies for the recycling and recovery of spent lithium-ion batteries. Renewable and Sustainable Energy Reviews 60:195-205

3. Reck BK and Graedel TE (2012) Challenges in Metal Recycling. Science 337(6095):690695

4. Izatt RM, Izatt SR, Bruening RL, Izatt NE, and Moyer BA (2014) Challenges to achievement of metal sustainability in our high-tech society. Chem. Soc. Rev. 43(8):24512475

5. Söderholm P and Ekvall T (2019) Metal markets and recycling policies: impacts and challenges. Mineral Economics 33(1-2):257-272

6. Ali GAM, Supriya S, Chong KF, Shaaban ER, Algarni H, Maiyalagan T, and Hegde G (2019) Superior supercapacitance behavior of oxygen self-doped carbon nanospheres: a conversion of Allium cepa peel to energy storage system. Biomass Conversion and Biorefinery

7. Ali GAM, Habeeb OA, Algarni H, and Chong KF (2018) CaO impregnated highly porous honeycomb activated carbon from agriculture waste: symmetrical supercapacitor study. Journal of Materials Science 54:683-692

8. Aboelazm EAA, Ali GAM, Algarni H, Yin H, Zhong YL, and Chong KF (2018) Magnetic Electrodeposition of the Hierarchical Cobalt Oxide Nanostructure from Spent Lithium-Ion Batteries: Its Application as a Supercapacitor Electrode. The Journal of Physical Chemistry C 122(23):12200-12206 
9. Habeeb OA, Ramesh K, Ali GAM, and Yunus RM (2017) Low-cost and eco-friendly activated carbon from modified palm kernel shell for hydrogen sulfide removal from wastewater: adsorption and kinetic studies. Desalination and Water Treatment 84:205-214

10. Habeeb OA, Ramesh K, Ali GAM, and Yunus RM (2017) Experimental design technique on removal of hydrogen sulfide using $\mathrm{CaO}$-eggshells dispersed onto palm kernel shell activated carbon: Experiment, optimization, equilibrium and kinetic studies. Journal of Wuhan University of Technology-Mater. Sci. Ed. 32(2):305-320

11. (!!! INVALID CITATION !!! [6-15])

12. Witik RA, Teuscher R, Michaud V, Ludwig C, and Månson J-AE (2013) Carbon fibre reinforced composite waste: An environmental assessment of recycling, energy recovery and landfilling. Composites Part A: Applied Science and Manufacturing 49:89-99

13. Kim TH, Senanayake G, Kang JG, Sohn JS, Rhee KI, Lee SW, and Shin SM (2009) Reductive acid leaching of spent zinc-carbon batteries and oxidative precipitation of $\mathrm{Mn}-$ Zn ferrite nanoparticles. Hydrometallurgy 96(1-2):154-158

14. Mylarappa M, Venkata Lakshmi V, Vishnu Mahesh KR, Nagaswarupa HP, and Raghavendra N (2019) Recovery of Mn-Zn ferrite from waste batteries and development of rGO/Mn-Zn ferrite nanocomposite for water purification. Materials Today: Proceedings 9:256-265

15. Xi G, Yang L, and Lu M (2006) Study on preparation of nanocrystalline ferrites using spent alkaline Zn-Mn batteries. Materials Letters 60(29-30):3582-3585

16. Morais VS, Barrada RV, Moura MN, Almeida JR, Moreira TFM, Gonçalves GR, Ferreira SAD, Lelis MFF, and Freitas MBJG (2020) Synthesis of manganese ferrite from spent Zn- 
$\mathrm{MnO}_{2}$ batteries and its application as a catalyst in heterogeneous photo-Fenton processes. Journal of Environmental Chemical Engineering 8(3):103716

17. Deng J, Wang X, Duan X, and Liu P (2015) Facile Preparation of $\mathrm{MnO}_{2} /$ Graphene Nanocomposites with Spent Battery Powder for Electrochemical Energy Storage. ACS Sustainable Chemistry \& Engineering 3(7):1330-1338

18. Duan X, Deng J, Wang X, Guo J, and Liu P (2016) Manufacturing conductive polyaniline/graphite nanocomposites with spent battery powder (SBP) for energy storage: A potential approach for sustainable waste management. Journal of Hazardous Materials $312: 319-328$

19. Xu J, Thomas HR, Francis RW, Lum KR, Wang J, and Liang B (2008) A review of processes and technologies for the recycling of lithium-ion secondary batteries. Journal of Power Sources 177(2):512-527

20. Ali GAM, Tan LL, Jose R, Yusoff MM, and Chong KF (2014) Electrochemical performance studies of $\mathrm{MnO}_{2}$ nanoflowers recovered from spent battery. Materials Research Bulletin 60:5-9

21. Ali GAM, Yusoff MM, Shaaban ER, and Chong KF (2017) High performance $\mathrm{MnO}_{2}$ nanoflower supercapacitor electrode by electrochemical recycling of spent batteries. Ceramics International 43:8440-8448

22. Aboelazm EAA, Ali GAM, and Chong KF (2018) Cobalt oxide supercapacitor electrode recovered from spent lithium-ion battery. Chemistry of Advanced Materials 3:67-74

23. Ali GAM (2020) Recycled $\mathrm{MnO}_{2}$ Nanoflowers and Graphene Nanosheets for Low-Cost and High Performance Asymmetric Supercapacitor. Journal of Electronic Materials 
24. Ali GAM, Yusoff MM, Algarni H, and Chong KF (2018) One-step electrosynthesis of $\mathrm{MnO}_{2} / \mathrm{rGO}$ nanocomposite and its enhanced electrochemical performance. Ceramics International

25. Song M, Cho Y, Yoon D, Nahm S, Oh S, Woo K, Ko J, and Cho W (2014) Solvothermal synthesis of $\mathrm{ZnMn}_{2} \mathrm{O}_{4}$ as an anode material in lithium ion battery. Electrochimica Acta $137: 266-272$

26. Smith WN, Arutunian M, and Swoffer S, Process for recycling alkaline batteries. 2013, Google Patents.

27. Ma Y, Cui Y, Zuo X, Huang S, Hu K, Xiao X, and Nan J (2014) Reclaiming the spent alkaline zinc manganese dioxide batteries collected from the manufacturers to prepare valuable electrolytic zinc and $\mathrm{LiNi}_{0.5} \mathrm{Mn}_{1.5} \mathrm{O}_{4}$ materials. Waste Management 34(10):17931799

28. Ali GAM, Yusoff MM, and Feng CK (2015) Electrochemical properties of electrodeposited $\mathrm{MnO}_{2}$ nanoparticles. Advanced Materials Research 1113:550-553

29. Xará S, Almeida MF, and Costa C (2015) Life cycle assessment of three different management options for spent alkaline batteries. Waste Management 43:460-484

30. Ali GAM, Manaf SAA, A D, Chong KF, and Hegde G (2016) Superior supercapacitive performance in porous nanocarbons. Journal of Energy Chemistry 25(4):734-739

31. Hegde G, Abdul Manaf SA, Kumar A, Ali GAM, Chong KF, Ngaini Z, and Sharma KV (2015) Biowaste sago bark based catalyst free carbon nanospheres: waste to wealth approach. ACS Sustainable Chemistry \& Engineering 5(9):2247-2253 
32. Ali GAM, Abdul Manaf SA, Kumar A, Chong KF, and Hegde G (2014) High performance supercapacitor using catalysis free porous carbon nanoparticles. Journal of Physics D: Applied Physics 47(49):495307-495313

33. Nan J, Han D, Cui M, Yang M, and Pan L (2006) Recycling spent zinc manganese dioxide batteries through synthesizing $\mathrm{Zn}-\mathrm{Mn}$ ferrite magnetic materials. Journal of Hazardous Materials 133(1-3):257-261

34. Gabal MA, Al-Harthy EA, Al Angari YM, Abdel Salam M, and Asiri AM (2016) Synthesis, characterization and magnetic properties of MWCNTs decorated with Znsubstituted $\mathrm{MnFe}_{2} \mathrm{O}_{4}$ nanoparticles using waste batteries extract. Journal of Magnetism and Magnetic Materials 407:175-181

35. Yao L, Xi Y, Xi G, and Feng Y (2016) Synthesis of cobalt ferrite with enhanced magnetostriction properties by the sol-gel-hydrothermal route using spent $\mathrm{Li}$-ion battery. Journal of Alloys and Compounds 680:73-79

36. Xi G-x, Jiao Y-z, and Lu M-x (2008) Preparation of $\mathrm{CoFe}_{2} \mathrm{O}_{4}$ nanocrystal from spent lithium-ion batteries with coprecipitation method. Electronic Components and Materials 27(5):19

37. Yang L, Xi G, Lou T, Wang X, Wang J, and He Y (2016) Preparation and magnetic performance of $\mathrm{Co}_{0.8} \mathrm{Fe}_{2.2} \mathrm{O}_{4}$ by a sol-gel method using cathode materials of spent Li-ion batteries. Ceramics International 42(1):1897-1902

38. Deep A, Kumar K, Kumar P, Kumar P, Sharma AL, Gupta B, and Bharadwaj LM (2011) Recovery of Pure $\mathrm{ZnO}$ Nanoparticles from Spent $\mathrm{Zn}-\mathrm{MnO}_{2}$ Alkaline Batteries. Environmental Science \& Technology 45(24):10551-10556 
39. Deep A, Sharma AL, Mohanta GC, Kumar P, and Kim K-H (2016) A facile chemical route for recovery of high quality zinc oxide nanoparticles from spent alkaline batteries. Waste Management 51:190-195

40. Mantuano DP, Dorella G, Elias RCA, and Mansur MB (2006) Analysis of a hydrometallurgical route to recover base metals from spent rechargeable batteries by liquid-liquid extraction with Cyanex 272. Journal of Power Sources 159(2):1510-1518

41. Qu J, Feng Y, Zhang Q, Cong Q, Luo C, and Yuan X (2015) A new insight of recycling of spent $\mathrm{Zn}-\mathrm{Mn}$ alkaline batteries: Synthesis of $\mathrm{Zn} \mathrm{Mn1-O}$ nanoparticles and solar light driven photocatalytic degradation of bisphenol A using them. Journal of Alloys and Compounds 622:703-707

42. Bennett JA, Wilson K, and Lee AF (2016) Catalytic applications of waste derived materials. Journal of Materials Chemistry A 4(10):3617-3637

43. Tang B, Yuan L, Shi T, Yu L, and Zhu Y (2009) Preparation of nano-sized magnetic particles from spent pickling liquors by ultrasonic-assisted chemical co-precipitation. Journal of Hazardous Materials 163(2-3):1173-1178

44. Khaloo SS, Torabbeigi M, Jazani RK, Douraghi M, and Ghalavand Z (2013) Laboratory waste minimization by recovery of silver as nano-silver colloidal dispersion from waste silver chloride. Journal of Material Cycles and Waste Management 15(3):342-347

45. Buzatu T, Popescu G, Birloaga I, and Săceanu S (2013) Study concerning the recovery of zinc and manganese from spent batteries by hydrometallurgical processes. Waste Management 33(3):699-705 
46. Sayilgan E, Kukrer T, Yigit NO, Civelekoglu G, and Kitis M (2010) Acidic leaching and precipitation of zinc and manganese from spent battery powders using various reductants. Journal of Hazardous Materials 173(1-3):137-143

47. Provazi K, Campos BA, Espinosa DCR, and Tenório JAS (2011) Metal separation from mixed types of batteries using selective precipitation and liquid-liquid extraction techniques. Waste Management 31(1):59-64

48. Toro L, Veglio F, Beolchini F, Pagnanelli F, Zanetti M, and Furlani G (2006) Process and plant for the treatment of run-down batteries. European Patent Application, EP (1):684

49. Giacinto V, Process for recovering potassium sulfate from ffinal mother liquors of kaineite. 1967, Google Patents.

50. Wen X, Qiao X, Han X, Niu L, Huo L, and Bai G (2015) Multifunctional magnetic branched polyethylenimine nanogels with in-situ generated $\mathrm{Fe}_{3} \mathrm{O}_{4}$ and their applications as dye adsorbent and catalyst support. Journal of Materials Science 51(6):3170-3181

51. Lannoo S, Vilas-Boas A, Sadeghi SM, Jesus J, and Soares HMVM (2019) An environmentally friendly closed loop process to recycle raw materials from spent alkaline batteries. Journal of Cleaner Production 236:117612

52. Xin B, Jiang W, Aslam H, Zhang K, Liu C, Wang R, and Wang Y (2012) Bioleaching of zinc and manganese from spent $\mathrm{Zn}-\mathrm{Mn}$ batteries and mechanism exploration. Bioresource Technology 106:147-153

53. Cui J and Zhang L (2008) Metallurgical recovery of metals from electronic waste: A review. Journal of Hazardous Materials 158(2-3):228-256 
54. Oliveira CRd, Bernardes AM, and Gerbase AE (2012) Collection and recycling of electronic scrap: A worldwide overview and comparison with the Brazilian situation. Waste Management 32(8):1592-1610

55. Zhan L and Xu Z (2008) Application of Vacuum Metallurgy to Separate Pure Metal from Mixed Metallic Particles of Crushed Waste Printed Circuit Board Scraps. Environmental Science \& Technology 42(20):7676-7681

56. Zhan L and Xu Z (2011) Separating and Recovering Pb from Copper-Rich Particles of Crushed Waste Printed Circuit Boards by Evaporation and Condensation. Environmental Science \& Technology 45(12):5359-5365

57. Zhan L and Xu Z (2009) Separating and Recycling Metals from Mixed Metallic Particles of Crushed Electronic Wastes by Vacuum Metallurgy. Environmental Science \& Technology 43(18):7074-7078

58. Xing M and Zhang F-S (2011) Nano-lead particle synthesis from waste cathode ray-tube funnel glass. Journal of Hazardous Materials 194:407-413

59. Saitoh S, Melber A, Ohbayashi H, Nakai S, Matsuoka M, and Hosomi M (2008) Simplified heating time calculation using the Schmidt graphical method for PCB-contaminated capacitors undergoing the vacuum thermal recycling process. Journal of Material Cycles and Waste Management 10(1):71-78

60. Ohbayashi H, Hosomi M, Kanbe H, Melber A, and Bruckamp J (2002) Removal of polychlorinated biphenyls from capacitors and pressure-sensitive paper by vacuum thermal recycling. Waste Management 22(1):91-98 
61. Saotome Y, Nakazawa Y, and Yamada Y (1999) Disassembling and materials recovering process of alkaline manganese dry batteries by vacuum-aided recycling systems technology (VARS Tech.). Vacuum 53(1-2):101-104

62. Huang K, Li J, and Xu Z (2009) A Novel Process for Recovering Valuable Metals from Waste Nickel-Cadmium Batteries. Environmental Science \& Technology 43(23):89748978

63. Kaya M (2016) Recovery of metals and nonmetals from electronic waste by physical and chemical recycling processes. Waste Management 57:64-90

64. Hirajima T, Bissombolo A, Sasaki K, Nakayama K, Hirai H, and Tsunekawa M (2005) Floatability of rare earth phosphors from waste fluorescent lamps. International Journal of Mineral Processing 77(4):187-198

65. Mallampati SR, Heo JH, and Park MH (2016) Hybrid selective surface hydrophilization and froth flotation separation of hazardous chlorinated plastics from E-waste with novel nanoscale metallic calcium composite. Journal of Hazardous Materials 306:13-23

66. He Y, Zhang T, Wang F, Zhang G, Zhang W, and Wang J (2017) Recovery of $\mathrm{LiCoO}_{2}$ and graphite from spent lithium-ion batteries by Fenton reagent-assisted flotation. Journal of Cleaner Production 143:319-325

67. Kachniarz M, Salach J, Szewczyk R, and Bieńkowski A, Temperature Influence on the Magnetic Characteristics of Mn-Zn Ferrite Materials, in Advances in Intelligent Systems and Computing. 2015, Springer International Publishing. p. 121-127.

68. Karpova TS, Vasil'ev VG, Vladimirova EV, and Nosov AP (2012) Synthesis of ferrite spinel $\mathrm{NiFe}_{2} \mathrm{O}_{4}$ by thermal hydrolysis and its magnetic properties. Inorganic Materials: Applied Research 3(2):107-112 
69. Cao C, Xia A, Liu S, and Tong L (2013) Synthesis and magnetic properties of hydrothermal magnesium-zinc spinel ferrite powders. Journal of Materials Science: Materials in Electronics 24(12):4901-4905

70. Tudorache F and Petrila I (2014) Effects of Partial Replacement of Iron with Tungsten on Microstructure, Electrical, Magnetic and Humidity Properties of Copper-Zinc Ferrite Material. Journal of Electronic Materials 43(9):3522-3526

71. Xi G, Li Y, and Liu Y (2004) Study on preparation of manganese-zinc ferrites using spent Zn-Mn batteries. Materials Letters 58(7-8):1164-1167

72. Peng C-h, Bai B-s, and Chen Y-f (2008) Study on the preparation of Mn-Zn soft magnetic ferrite powders from waste Zn-Mn dry batteries. Waste Management 28(2):326-332

73. Lu L, Fang Y, Huang Z, Huang Y, and Ren ZJ (2016) Self-sustaining carbon capture and mineralization via electrolytic carbonation of coal fly ash. Chemical Engineering Journal $306: 330-335$

74. Huang TY, Chiueh PT, and Lo SL (2017) Life-cycle environmental and cost impacts of reusing fly ash. Resources, Conservation and Recycling 123:255-260

75. Li S and Wang X-m (2016) Fly-ash-based magnetic coagulant for rapid sedimentation of electronegative slimes and ultrafine tailings. Powder Technology 303:20-26

76. Li S, Wang X-m, and Zhang Q-1 (2016) Dynamic experiments on flocculation and sedimentation of argillized ultrafine tailings using fly-ash-based magnetic coagulant. Transactions of Nonferrous Metals Society of China 26(7):1975-1984

77. Lin K-S, Chiang C-L, Hsu P-J, Bat-Erdene K, Tang C-Y, and Wu C-M (2018) Magnetic separation and recycling of ferrite nanocatalysts for $\mathrm{CO}_{2}$ decomposition with $\mathrm{CH}_{4}$ recovery from steel industrial flyash. Catalysis Today 307:260-271 
78. Kim G-Y, Jeon J-H, Kim M-H, Suvorov D, and Choi S-Y (2013) Microstructural development of cobalt ferrite ceramics and its influence on magnetic properties. Metals and Materials International 19(6):1209-1213

79. Emamian HR, Honarbakhsh-Raouf A, Ataie A, and Mirzaee O (2015) Characterization of mesoporous nanostructured cobalt ferrite foams fabricated by microwave and conventional sintering routes. Journal of Porous Materials 22(3):603-611

80. Amiri M, Salavati-Niasari M, Akbari A, and Razavi R (2017) Sol-gel auto-combustion synthesize and characterization of a novel anticorrosive cobalt ferrite nanoparticles dispersed in silica matrix. Journal of Materials Science: Materials in Electronics 28(14):10495-10508

81. Khan K (2014) Microwave Absorption Properties of Radar Absorbing Nanosized Cobalt Ferrites for High Frequency Applications. Journal of Superconductivity and Novel Magnetism 27(2):453-461

82. Zhou J-p, Fu W-1, Qiu K-q, and Chen Q-y (2007) Photocatalytic properties of nano tetrapod-like zinc oxide whiskers. Journal of Functional Materials and Devices 13(3):195

83. Guo X, Zhong J, Song Y, and Tian Q (2010) Substance flow analysis of zinc in China. Resources, Conservation and Recycling 54(3):171-177

84. Zhan L, Li O, Wang Z, and Xie B (2018) Recycling Zinc and Preparing High-Value-Added Nanozinc Oxide from Waste Zinc-Manganese Batteries by High-Temperature Evaporation-Separation and Oxygen Control Oxidation. ACS Sustainable Chemistry \& Engineering 6(9):12104-12109 
85. Zhan L, Li O, and Xu Z (2020) Preparing nano-zinc oxide with high-added-value from waste zinc manganese battery by vacuum evaporation and oxygen-control oxidation. Journal of Cleaner Production 251:119691

86. Li L, Qiu K, and Chen Q (2003) Status and problems on waste dry battery recycling research in China. NONFERROUS METALS-BEIJING- 55(2):122-126

87. Xie Y, Wang S, Tian X, Che L, Wu X, and Zhao F (2019) Leaching of indium from endof-life LCD panels via catalysis by synergistic microbial communities. Science of The Total Environment 655:781-786

88. Lahtela V, Virolainen S, Uwaoma A, Kallioinen M, Kärki T, and Sainio T (2019) Novel mechanical pre-treatment methods for effective indium recovery from end-of-life liquidcrystal display panels. Journal of Cleaner Production 230:580-591

89. Bekheet MF, Schwarz MR, Lauterbach S, Kleebe HJ, Kroll P, Riedel R, and Gurlo A (2013) Orthorhombic $\operatorname{In}_{2} \mathrm{O}_{3}$ : a metastable polymorph of indium sesquioxide. Angewandte Chemie International Edition 52(25):6531-6535

90. Bekheet MF, Schwarz MR, Lauterbach S, Kleebe H-J, Kroll P, Stewart A, Kolb U, Riedel R, and Gurlo A (2013) In situ high pressure high temperature experiments in multi-anvil assemblies with bixbyite-type $\operatorname{In}_{2} \mathrm{O}_{3}$ and synthesis of corundum-type and orthorhombic $\mathrm{In}_{2} \mathrm{O}_{3}$ polymorphs. High pressure research 33(3):697-711

91. Bekheet MF, Schwarz MR, Kroll P, and Gurlo A (2015) Kinetic control in the synthesis of metastable polymorphs: bixbyite-to- $\mathrm{Rh}_{2} \mathrm{O}_{3}$ (II)-to-corundum transition in $\mathrm{In}_{2} \mathrm{O}_{3}$. Journal of Solid State Chemistry 229:278-286 
92. De Boer T, Bekheet M, Gurlo A, Riedel R, and Moewes A (2016) Band gap and electronic structure of cubic, rhombohedral, and orthorhombic $\mathrm{In}_{2} \mathrm{O}_{3}$ polymorphs: Experiment and theory. Physical Review B 93(15):155205

93. Boundy T, Boyton M, and Taylor P (2017) Attrition scrubbing for recovery of indium from waste liquid crystal display glass via selective comminution. Journal of Cleaner Production $154: 436-444$

94. Bekheet MF, Miehe G, Fasel C, Gurlo A, and Riedel R (2012) Low temperature synthesis of nanocrystalline $\mathrm{MnIn}_{2} \mathrm{O}_{4}$ spinel. Dalton Transactions 41(12):3374-3376

95. Schlicker L, Bekheet MF, Gili A, Doran A, Gurlo A, Ploner K, Schachinger T, and Penner S (2018) Hydrogen reduction and metal-support interaction in a metastable metal-oxide system: Pd on rhombohedral $\operatorname{In}_{2} \mathrm{O}_{3}$. Journal of Solid State Chemistry 266:93-99

96. Zhuang XN, Ye YY, He WZ, Li GM, and Huang JW (2014) Hydrothermal Treatment of Liquid Crystal Using a Batch Reactor. Advanced Materials Research 878:563-568

97. Virolainen S, Ibana D, and Paatero E (2011) Recovery of indium from indium tin oxide by solvent extraction. Hydrometallurgy 107:56-61

98. Pa P-s (2009) Effective tool design of three-rank form as precision removal-process of ITO thin-films. Transactions of Nonferrous Metals Society of China 19:s232-s237

99. Inoue K, Nishiura M, Kawakita H, Ohto K, and Harada H (2008) Recovery of Indium from Spent Panel of Liquid Crystal Display Panels. KAGAKU KOGAKU RONBUNSHU 34(2):282-286

100. Rocchetti L, Amato A, and Beolchini F (2016) Recovery of indium from liquid crystal displays. Journal of Cleaner Production 116:299-305 
101. Zhang K, Wu Y, Wang W, Li B, Zhang Y, and Zuo T (2015) Recycling indium from waste LCDs: A review. Resources, Conservation and Recycling 104:276-290

102. Wang S, He Y, Zhang T, and Zhang G (2017) Recovery of valuable components from waste LCD panel through a dry physical method. Waste Management 64:255-262

103. Savvilotidou V, Hahladakis JN, and Gidarakos E (2014) Determination of toxic metals in discarded Liquid Crystal Displays (LCDs). Resources, Conservation and Recycling 92:108-115

104. Li J, Gao S, Duan H, and Liu L (2009) Recovery of valuable materials from waste liquid crystal display panel. Waste Management 29(7):2033-2039

105. Lee C-H, Jeong M-K, Fatih Kilicaslan M, Lee J-H, Hong H-S, and Hong S-J (2013) Recovery of indium from used LCD panel by a time efficient and environmentally sound method assisted HEBM. Waste Management 33(3):730-734

106. Ruan J, Guo Y, and Qiao Q (2012) Recovery of Indium from Scrap TFT-LCDs by Solvent Extraction. Procedia Environmental Sciences 16:545-551

107. Hsieh S-J, Chen C-C, and Say WC (2009) Process for recovery of indium from ITO scraps and metallurgic microstructures. Materials Science and Engineering: B 158(1-3):82-87

108. Ma E and Xu Z (2013) Technological process and optimum design of organic materials vacuum pyrolysis and indium chlorinated separation from waste liquid crystal display panels. Journal of Hazardous Materials 263:610-617

109. Park K-S, Sato W, Grause G, Kameda T, and Yoshioka T (2009) Recovery of indium from $\mathrm{In}_{2} \mathrm{O}_{3}$ and liquid crystal display powder via a chloride volatilization process using polyvinyl chloride. Thermochimica Acta 493(1-2):105-108 
110. Zhang L, Wu B, Chen Y, and Xu Z (2017) Energy and valuable resource recovery from waste liquid crystal display panels by an environment-friendly technological process: Pyrolysis of liquid crystals and preparation of indium product. Journal of Cleaner Production 162:141-152

111. He Y, Ma E, and Xu Z (2014) Recycling indium from waste liquid crystal display panel by vacuum carbon-reduction. Journal of Hazardous Materials 268:185-190

112. Yoshida H, Izhar S, Nishio E, Utsumi Y, Kakimori N, and Asghari Feridoun S (2014) Recovery of indium from TFT and CF glasses in LCD panel wastes using sub-critical water. Solar Energy Materials and Solar Cells 125:14-19

113. Higashi A, Saitoh N, Ogi T, and Konishi Y (2011) Recovery of Indium by Biosorption and Its Application to Recycling of Waste Liquid Crystal Display Panel. Journal of the Japan Institute of Metals 75(11):620-625

114. Wang S, He Y, Yang J, and Feng Y (2018) Enrichment of indium tin oxide from colour filter glass in waste liquid crystal display panels through flotation. Journal of Cleaner Production 189:464-471

115. Wang S, He Y, Feng Y, Zhang F, and Zhang T (2020) Indium tin oxide recycling from waste colour filter glass via thermal decomposition. Journal of Hazardous Materials $392: 122503$ 